\title{
Water-Quality Assessment of Southern Florida: An Overview of Available Information on Surface- and Ground-Water Quality and Ecology
}

By Kim H. Haag, Ronald L. Miller, Laura A. Bradner, and David S. McCulloch

U.S. Geological Survey

Water-Resources Investigations Report 96-4177

Prepared as part of the

National Water-Quality Assessment Program

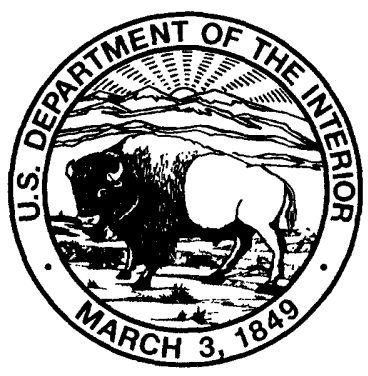




\section{FOREWORD}

The mission of the U.S. Geological Survey (USGS) is to assess the quantity and quality of the earth resources of the Nation and to provide information that will assist resource managers and policymakers at Federal, State, and local levels in making sound decisions. Assessment of water-quality conditions and trends is an important part of this overall mission.

One of the greatest challenges faced by water-resources scientists is acquiring reliable information that will guide the use and protection of the Nation's water resources. That challenge is being addressed by Federal, State, interstate, and local water-resource agencies and by many academic institutions. These organizations are collecting water-quality data for a host of purposes that includes: compliance with permits and water-supply standards; development of remediation plans for a specific contamination problem; operational decisions on industrial, wastewater, or water-supply facilities; and research on factors that affect water quality. An additional need for water-quality information is to provide a basis on which regional and national-level policy decisions can be based. Wise decisions must be based on sound information. As a society we need to know whether certain types of water-quality problems are isolated or ubiquitous, whether there are significant differences in conditions among regions, whether the conditions are changing over time, and why these conditions change from place to place and over time. The information can be used to help determine the efficacy of existing water-quality policies and to help analysts determine the need for and likely consequences of new policies.

To address these needs, the Congress appropriated funds in 1986 for the USGS to begin a pilot program in seven project areas to develop and refine the National Water-Quality Assessment (NAWQA) Program. In 1991, the USGS began full implementation of the program. The NAWQA Program builds upon an existing base of water-quality studies of the USGS, as well as those of other Federal, State, and local agencies. The objectives of the NAWQA Program are to:

- Describe current water-quality conditions for a large part of the Nation's freshwater streams, rivers, and aquifers.

- Describe how water quality is changing over time.

- Improve understanding of the primary natural and human factors that affect water-quality conditions.

This information will help support the development and evaluation of management, regulatory, and monitoring decisions by other Federal, State, and local agencies to protect, use, and enhance water resources.

The goals of the NAWQA Program are being achieved through ongoing and proposed investigations of 60 of the Nation's most important river basins and aquifer systems, which are referred to as study units. These study units are distributed throughout the Nation and cover a diversity of hydrogeologic settings. More than two-thirds of the Nation's freshwater use occurs within the 60 study units and more than two-thirds of the people served by public water-supply systems live within their boundaries.

National synthesis of data analysis, based on aggregation of comparable information obtained from the study units, is a major component of the program. This effort focuses on selected water-quality topics using nationally consistent information. Comparative studies will explain differences and similarities in observed water-quality conditions among study areas and will identify changes and trends and their causes. The first topics addressed by the national synthesis are pesticides, nutrients, volatile organic compounds, and aquatic biology. Discussions on these and other water-quality topics will be published in periodic summaries of the quality of the Nation's ground and surface water as the information becomes available.

This report is an element of the comprehensive body of information developed as part of the NAWQA Program. The program depends heavily on the advice, cooperation, and information from many Federal, State, interstate, Tribal, and local agencies and the public. The assistance and suggestions of all are greatly appreciated.

Robert M. Hirsch

Chief Hydrologist 
IV Contents 


\section{CONTENTS}

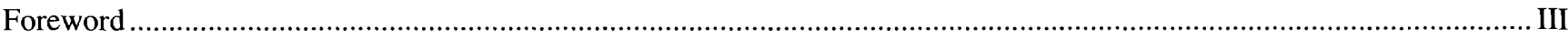

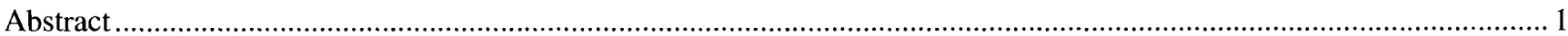

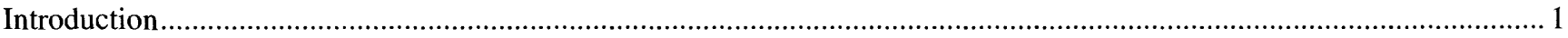

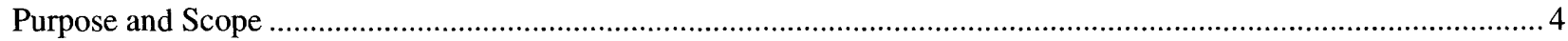

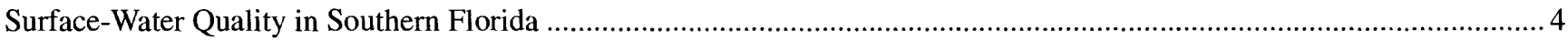

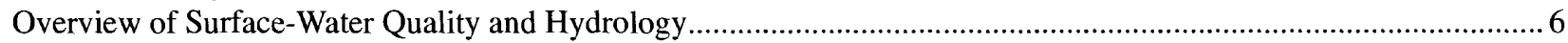

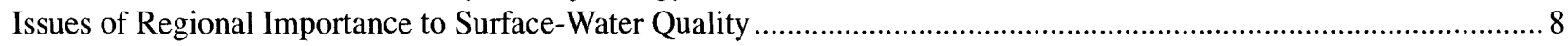

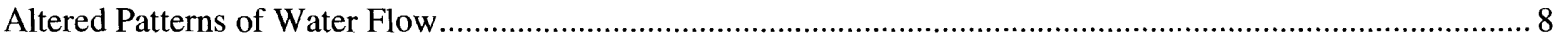

Relation of Atmospheric Deposition to Surface-Water Quality ......................................................................... 9

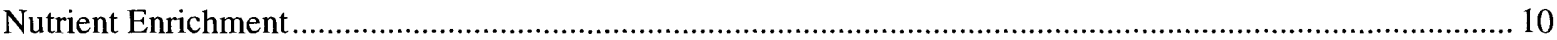

Pesticides and Other Organic Compounds in Water and Sediment ……...................................................... 12

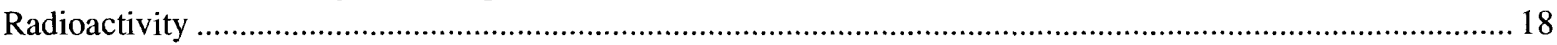

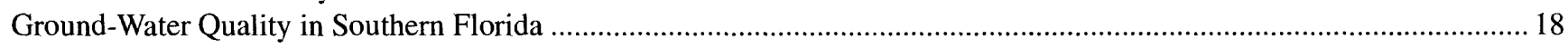

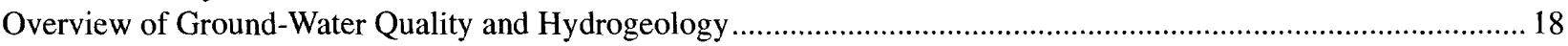

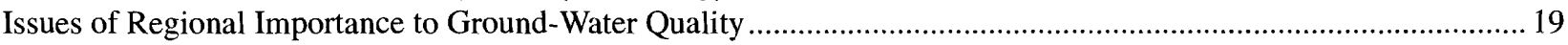

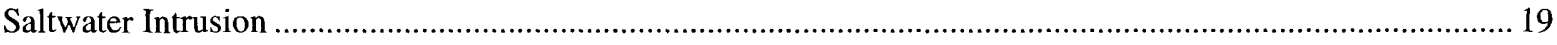

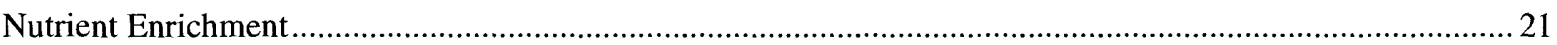

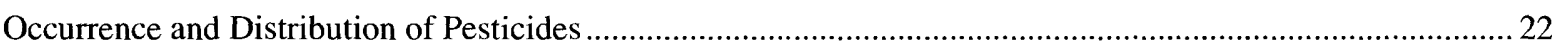

Volatile Organic Compounds............................................................................................................ 22

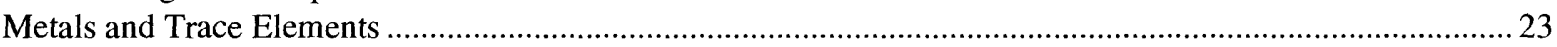

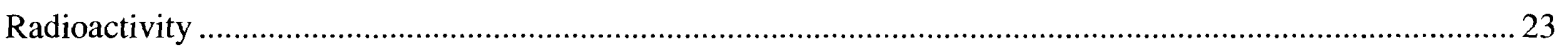

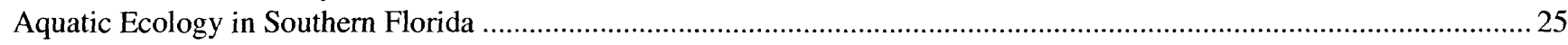

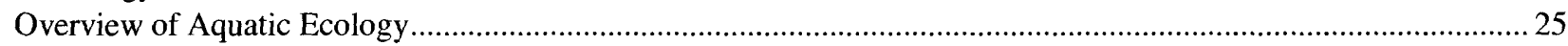

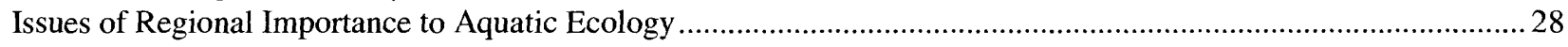

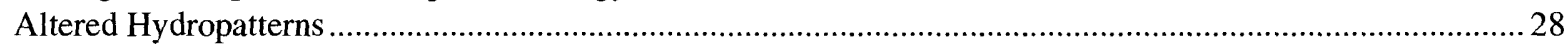

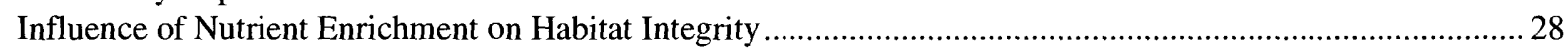

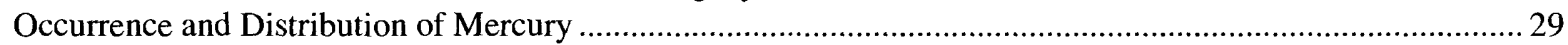

Endocrine Disruption and Other Effects of Pesticides on Biota ................................................................... 30

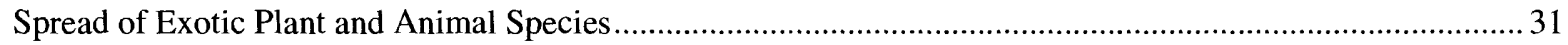

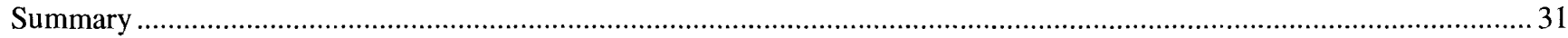

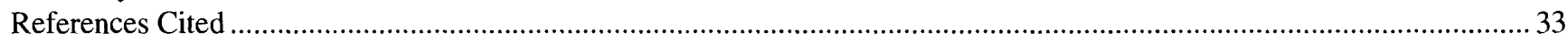

Appendix: Data Sources and Computation Methods Used for Pie Diagrams of Estimated Nutrient Loads

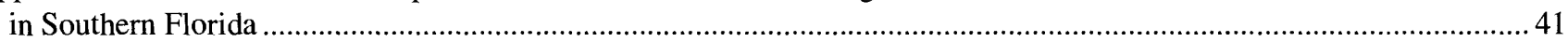

\section{FIGURES}

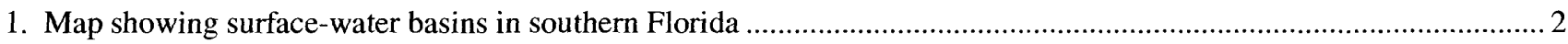

2. Map showing major canals, control structures, and other hydrologic features in southern Florida ..............................5

3. Pie charts showing estimated phosphorus loading from point and nonpoint sources in surface-water basins in southern Florida

4. Pie charts showing estimated nitrogen loading from point and nonpoint sources in surface-water basins in southern Florida

5-8. Maps showing:

5. Estimated total phosphorus loads for selected canal and river outflows from surface-water basins in southern Florida

6. Estimated total nitrogen loads for selected canal and river outflows from surface-water basins in southern Florida ....... 17

7. Aquifer systems in southern Florida and extent of peat in the Everglades region .............................................. 20

8. Occurrence of hydrogenated aliphatic and monocyclic aromatic hydrocarbons in ground water in southern Florida number of water utilities with untreated water samples in which concentrations of halogenated aliphatic hydrocarbons exceeded drinking-water guidance concentrations; number of water utilities with untreated water samples in which concentrations of monocyclic aromatic hydrocarbons exceeded drinking-water guidance concentrations; number of background wells in which halogenated aliphatic hydrocarbons were detected in water samples; number of background wells in which monocyclic aromatic hydrocarbons were detected in water samples. 


\section{Tables}

1. Average nutrient concentrations in precipitation at selected sites in Florida, 1990-92 ...............................................10

2. Estimated annual atmospheric loading of nitrogen and phosphorus at selected sites in Florida .....................................11

3. Estimates of nitrogen and phosphorus inputs to drainage basins in the Southern Florida NAWQA study unit .................15

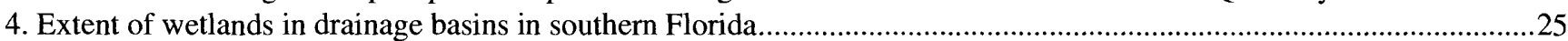

\section{CONVERSION FACTORS, VERTICAL DATUM, AND ABBREVIATIONS}

\begin{tabular}{rcl}
\hline Multiply & By & To obtain \\
\hline square meter $\left(\mathrm{m}^{2}\right)$ & 0.0002471 & acre \\
hectare $(\mathrm{ha})$ & 2.471 & acre \\
square kilometer $\left(\mathrm{km}^{2}\right)$ & 247.1 & acre \\
cubic meter $\left(\mathrm{m}^{3}\right)$ & 35.31 & cubic foot \\
meter $(\mathrm{m})$ & 3.281 & foot \\
meter per second $(\mathrm{m} / \mathrm{s})$ & 3.281 & foot per second \\
liter $(\mathrm{L})$ & 0.2642 & gallon \\
centimeter $(\mathrm{cm})$ & 0.3937 & inch \\
centimeter per year $(\mathrm{cm} / \mathrm{yr})$ & 0.3937 & inch per year \\
centimeters per kilometer $(\mathrm{cm} / \mathrm{km})$ & 0.6239 & inch per mile \\
kilometer $(\mathrm{km})$ & 0.6214 & mile \\
kilometer per day $(\mathrm{km} / \mathrm{d})$ & 0.6214 & mile per day \\
kilogram & 2.2046 & pound \\
square kilometer $\left.(\mathrm{km})^{2}\right)$ & 0.3861 & square mile \\
megagram $(\mathrm{Mg})$ & 1.016 & ton \\
\hline
\end{tabular}

Degrees Celsius $\left({ }^{\circ} \mathrm{C}\right)$ may be converted to degrees Fahrenheit $\left({ }^{\circ} \mathrm{F}\right)$ by use of the following equation: ${ }^{\circ} \mathrm{F}=(9 / 5)\left({ }^{\circ} \mathrm{C}\right)+32$

Sea level: In this report, "sea level" refers to the National Geodetic Vertical Datum of 1929 (NGVD of 1929)--a geodetic datum derived from a general adjustment of the first-order level nets of the United States and Canada, formerly called Sea Level Datum of 1929.

Abbreviated water-quality units used in this report: Chemical concentrations and water temperatures are given in metric units. Chemical concentration is given in milligrams per liter $(\mathrm{mg} / \mathrm{L})$ or micrograms per liter $(\mu \mathrm{g} / \mathrm{L})$. Milligrams per liter is a unit expressing the concentration of chemical constituents in solution as weight (milligrams) of solute per unit volume (liter) of water. One thousand micrograms per liter is equivalent to one milligram per liter. For concentrations less than $7,000 \mathrm{mg} / \mathrm{L}$, the numerical value is the same as the concentration in parts per million.

\section{ADDITIONAL ABBREVIATIONS}

BCNP Big Cypress National Preserve

BNRP Broward County Department of Natural Resource Protection

DERM Dade County Environmental Resource Management

EAA Everglades Agricultural Area

ENP Everglades National Park

FDEP Florida Department of Environmental Protection

FGFWFC Florida Game and Freshwater Fish Commission

LEC Lower East Coast

NPS National Park Service

SFWMD South Florida Water Management District

STA Stormwater Treatment Area

SWFWMD Southwest Florida Water Management District

USACE U.S. Army Corps of Engineers

USEPA U.S. Environmental Protection Agency

USFWS U.S. Fish and Wildlife Service

USGS U.S. Geological Survey

WCA Water Conservation Area

\section{CHEMICAL ABBREVIATIONS}

BHC hexachlorocyclohexane

DDE I' (2,2-dichloroethenylidene)bis[4-chlorobenzene]

DDT 1' 92,2,2-trichloroethenylidene)bis[4-chlorobenzene]

EBDC ethylenebisdithiocarbamates

EDB ethylene dibromide

MSMA monosodium methanearsonate

PAH polyaromatic hydrocarbons

PCB polychlorinated biphenyl

VOC volatile orcanic carbon

ppm parts per million

$\mathrm{ppb}$ parts per billion

$\mathrm{pCI} / \mathrm{L}$ picocuries per liter

$\mu \mathrm{g} / \mathrm{L}$ micrograms per liter

$\mathrm{mg} / \mathrm{L}$ milligrams per liter

$<$ less than

$>$ greater than 


\title{
U.S. DEPARTMENT OF THE INTERIOR BRUCE BABBITT, Secretary
}

\author{
U.S. GEOLOGICAL SURVEY \\ Gordon P. Eaton, Director
}

Any use of trade, product, or firm names in this publication is for descriptive purposes only and does not imply endorsement by the U.S. Geological Survey.

For additional information write to:

\section{District Chief}

U.S. Geological Survey

Suite 3015

227 N. Bronough Street

Tallahassee, FL 32301
Copies of this report can be purchased from:

U.S. Geological Survey

Branch of Information Services

Box 25286

Denver, CO 80225 


\title{
Water-Quality Assessment of Southern Florida: An Overview of Available Information on Surface- and Ground-Water Quality and Ecology
}

\author{
By Kim H. Haag, Ronald L. Miller, Laura A. Bradner, and David S. McCulloch
}

\section{Abstract}

This report summarizes water-quality conditions, issues of concern, and management efforts underway in southern Florida. The report is designed to provide a conceptual framework for the Southern Florida National Water Quality Assessment (NAWQA) study that began in 1994. The report makes reference to the most important waterquality literature pertaining to southern Florida, to water-quality studies that are underway or planned, and to topics which are of high priority in the study unit. These topics include: the availability and suitability of water for competing demands; nutrient enrichment of the Everglades; transport, degradation, and effects of pesticides; and the sources and cycling of mercury in the ecosystem.

The report also includes a retrospective analysis and conceptual presentation of nutrient loading, which is a high priority for the national NAWQA Program and for regional water-quality managers. Nutrient contributions from point and nonpoint sources are estimated for nine basins in the study area and are discussed in relation to land use. Fertilizer is the dominant source of phosphorus in eight basins and the dominant source of nitrogen in at least five basins. Atmospheric sources of nitrogen contribute more than 20 percent of the total nitrogen input to all basins and are the dominant source of nitrogen input to Lake Okeechobee and the Everglades.
Nutrient loads are also estimated in selected canal and river outflows in southern Florida to provide a spatial overview of the magnitude of nutrient loading to coastal waters. Annual phosphorus loads from the Peace River are the highest in the study unit; annual phosphorus loads from the Caloosahatchee River and the major Palm Beach canals are also high, compared to other parts of southern Florida. Estimated annual loads of phosphorus from parts of the Big Cypress Basin and the S-12 watercontrol structures of the Tamiami Canal are low compared with estimated phosphorus loads in outflows in the northern part of the study unit. Annual nitrogen loads in southern Florida were highest in outflows from the Caloosahatchee River Basin and the major Palm Beach canals. Nitrogen loads in outflows from parts of the Big Cypress subbasin were lower than those estimated to the north.

\section{INTRODUCTION}

The Southern Florida National Water Quality Assessment (NAWQA) study unit encompasses about $50,500 \mathrm{~km}^{2}$. It is part of a regional ecosystem which includes coastal waters between Charlotte Harbor on the Gulf of Mexico and the St. Lucie River on the Atlantic Ocean and the lands that drain into these waters (fig. 1). The elevation in the study unit ranges from about $90 \mathrm{~m}$ above sea level to sea level along the coast. The climate is subtropical and humid with mean temperatures ranging from about $15^{\circ} \mathrm{C}$ in the winter to about $27^{\circ} \mathrm{C}$ in summer (Florida Department of Natural Resources, 1974; Duever and others, 1994). Average annual rainfall ranges from 100 to $1,075 \mathrm{~cm}$, and more than half of the rainfall occurs in the wet season from June through September (Thomas, 1974). 


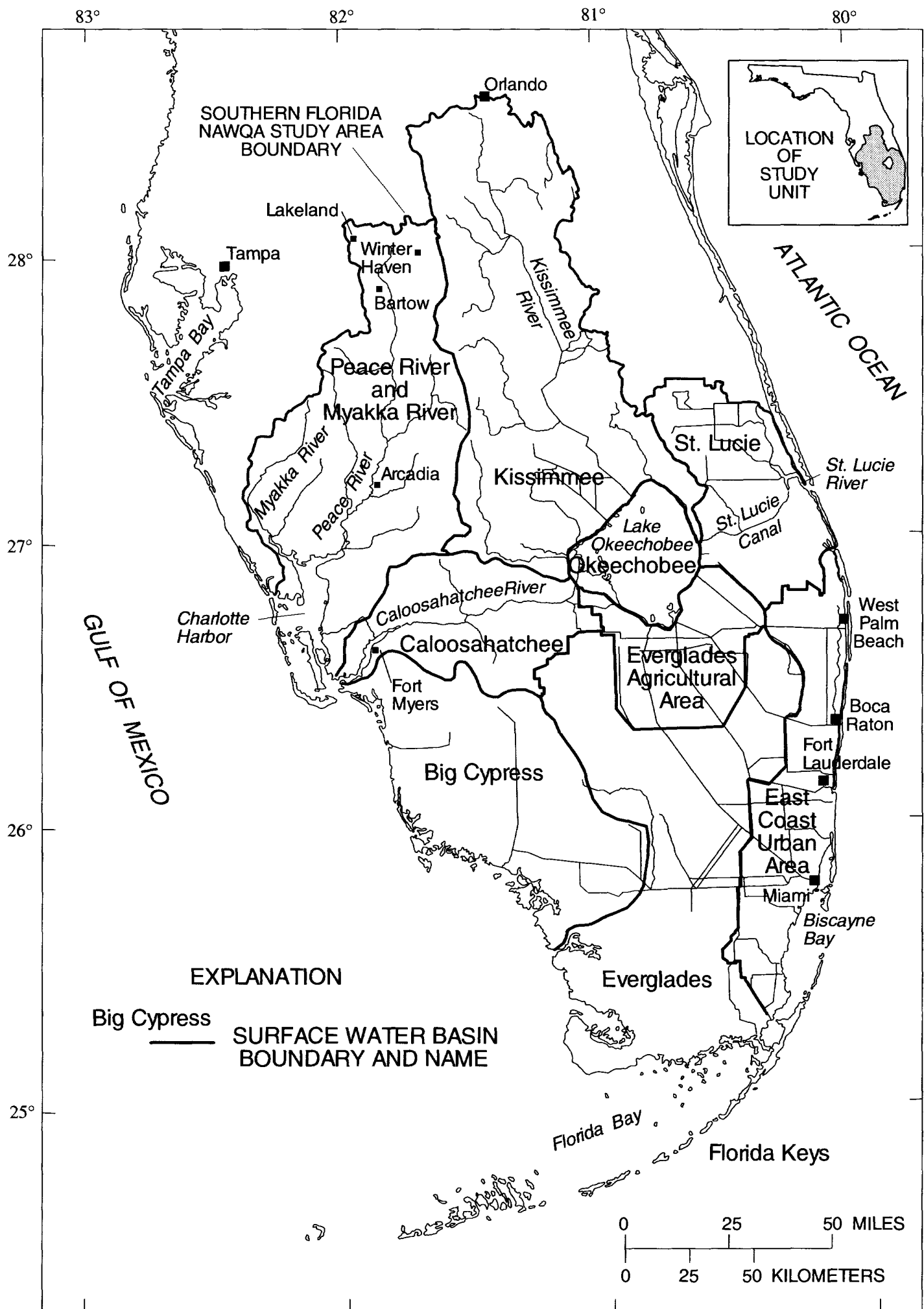

Base from U.S. Geological Survey digital data, 1:2,000,000, 1972

Albers Equal-Area Conic projection

Standard Parallels $29^{\circ} 30^{\prime}$ and $45^{\circ} 30^{\prime}$, central meridian $-83^{\circ} 00^{\prime}$

Figure 1. Surface-water basins in southern Florida. 
Southern Florida is underlain by shallow-marine carbonate sediments that contain three major aquifers systems - the surficial, intermediate, and Floridan. Wetlands are a predominant feature of the landscape and are maintained as a result of abundant rainfall and the absence of surface relief. Wetlands in the northern part of the study unit are drained by several large rivers that include the Kissimmee, Peace, Myakka, and Caloosahatchee Rivers. In the southern part of the study unit, much of the land is inundated during the wet season, and water moves by sheetflow toward the coast. The Everglades is a vast freshwater marsh originally covering about $10,000 \mathrm{~km}^{2}$ and extending from the southern edge of Lake Okeechobee south to Florida Bay. The Everglades Basin has an almost imperceptible slope to the south, averaging less than $3 \mathrm{~cm} / \mathrm{km}$. The Big Cypress Basin to the west of the Everglades is on slightly higher ground. The land surface is relatively flat with numerous, low limestone outcrops and depressions. Water in the Big Cypress Basin drains to the south and southwest through cypress strands into the coastal mangrove forest. The Florida Keys is a series of low limestone islands extending $225 \mathrm{~km}$ southwest of the mainland. The physiography, climate, geology, and hydrology of the south Florida region are described more fully by McPherson and Halley (1996).

The ecosystem in southern Florida has undergone significant alteration over the past century, principally in response to the demands of a growing population. Activities included extensive drainage and development. When the initial alterations began, understanding and appreciation of the value and function of wetlands was very limited. Once the effects of drainage and development became evident and began to affect the environment, efforts turned towards restoration. Initial data-gathering efforts focused on studies of water supply, water use, and flood prevention. During the 1970's, an awareness of the importance of water-quality and habitat protection emerged. Of particular interest are the effects of pesticides, trace elements, and excess nutrients on water quality and aquatic ecology. Among the most active agencies gathering data in southern Florida are the Florida Department of Environmental Protection (FDEP), the Florida Game and Freshwater Fish Commission (FGFWFC), the National Biological Service (NBS), the National Park Service (NPS), the National Atmospheric and Oceanic Administration (NOAA), the South Florida Water Management District (SFWMD), the Southwest Florida Water Management District (SWFWMD), the U.S. Geo- logical Survey (USGS), the U.S. Army Corps of Engineers (USACE), the U.S. Fish and Wildlife Service (USFWS), and the U.S. Environmental Protection Agency (USEPA). Other organizations which actively study water quality in southern Florida include several county governments, Duke University, the Florida Institute of Technology, Florida International University, Louisiana State University, the University of Florida, and the University of Miami. Numerous individuals have also published information relevant to water quality and ecology in southern Florida.

The study of surface- and ground-water quality and aquatic ecology in the southern Florida ecosystem has a long history. The amount of available data is tremendous and a brief summary of all available water-quality and ecological data is beyond the scope of this report. For example, the SFWMD alone operates 26 major water-quality monitoring programs that incorporate 984 sampling stations. Much of the retrospective data available through 1994 was collected by missionoriented agencies to address strictly defined regulatory issues, answer specific questions in the context of resource utilization, or provide guidance for resource management within a single watershed. Although these data have unquestioned utility, they often cannot be used to answer questions which involve multiple watersheds or address more complex water-quality issues. Among the most important water-quality questions being addressed in southern Florida in the 1990's are:

- What is the availability and suitability of water for competing demands?

- What key components of the hydrologic system are needed to support a diverse, self-sustaining ecosystem?

- How does atmospheric deposition influence surface-water quality?

- Are contaminants from human activities widespread, and do they adversely affect ecosystems?

- What are the processes that transform and transport nutrients?

- What are the origins and pathways for the cycling of mercury in the ecosystem?

There are several important, broadly based, environmental programs now underway in southern Florida that address these and related questions (South Florida Water Management District, 1995). Everglades water-quality litigation was filed by the Federal Government in 1988 and resolved by a negotiated State-Federal settlement 
agreement in 1991. One goal of the settlement was to establish long-term limits on phosphorus concentrations for the Arthur R. Marshall Loxahatchee National Wildlife Refuge and the Everglades National Park.

In 1993, the South Florida Ecosystem Restoration Task Force was formed to initiate an interagency effort to reestablish and maintain the ecosystem integrity of southern Florida. The Task Force is composed of Federal and State agencies involved in Everglades restoration. In 1994, Florida passed the Everglades Forever Act to initiate restoration of the Everglades and Florida Bay. The area identified for restoration and protection by the act is called the Everglades Protection Area and is comprised of the Everglades National Park (ENP) and the Water Conservation Areas (WCAs): WCA-1 (the Arthur R. Marshall Loxahatchee National Wildlife Refuge), WCA-2, and WCA-3 (fig. 2). The Everglades Protection Area encompasses a total of about 810,000 ha. Two major components of the act are:

- The Everglades Construction Project, which will entail construction of more than 16,200 ha of wetlands called Stormwater Treatment Areas (STAs) designed to remove nutrients (specifically phosphorus) and other contaminants from agricultural stormwater runoff from the Everglades Agricultural Area (EAA); and

- Implementation of on-farm Best Management Practices for reduction of nutrient loads from the EAA, which produces about 45 percent of the phosphorus load to the Everglades.

The Everglades Water Quality Model is being developed and tested by the SFWMD in support of the act and to evaluate the efficacy of the Everglades Nutrient Removal Project (South Florida Water Management District, 1995).

In 1993, the USEPA initiated a program of research, monitoring, and regulatory efforts to determine the sources, extent, transport, transformation, and pathways of mercury in southern Florida ecosystems. This initiative is a part of the USEPA Regional Environmental Monitoring and Assessment Program (U.S. Environmental Protection Agency, 1993). Since 1995, the USGS has provided multidisciplinary hydrologic, cartographic, and geologic data that relate to the mainland of southern Florida, Florida Bay, and the Florida Keys and Reef ecosystems, as a part of the USGS South Florida Ecosystem Program (U.S. Geological Survey, 1995).
A recent consensus has emerged that agencies and individuals must go beyond a mere assessment and understanding of the southern Florida environment and begin to protect the remaining natural system and restore some watersheds to predevelopment waterquality conditions and patterns of hydrologic function. The USGS is committed to providing scientific information that will contribute to the protection and restoration effort in southern Florida (McPherson and Halley, 1996).

\section{Purpose and Scope}

This report was written as part of the retrospective analysis of existing data and information for the Southern Florida NAWQA. Surface-water quality, groundwater quality, and aquatic ecology are closely related in southern Florida and are difficult to discuss separately. Nevertheless, they are covered in separate sections of this report to be consistent with other reports of the national NAWQA Program. The report briefly: (1) summarizes relevant published water-quality and ecological information pertaining to southern Florida; (2) describes selected regional conditions, trends, and issues of importance to surface- and ground-water quality and ecology; (3) suggests possible relations of water quality and ecology to natural and human factors; (4) indicates what types of water-quality and ecological data are lacking; and (5) presents a conceptual description of nutrient loading in surface waters of southern Florida. The report will be used to help develop a study plan for the Southern Florida NAWQA and to provide information to the NAWQA National Synthesis Team for incorporation into the nationwide synthesis of water-quality information.

\section{SURFACE-WATER QUALITY IN SOUTHERN FLORIDA}

Many factors influence surface-water quality in the watersheds of southern Florida. A short description of historical conditions and a summary of the major alterations which have occurred as a result of human activities in south Florida are presented. A brief overview of available surface-water-quality data and a brief discussion of important water-quality issues is presented in this report to provide a framework for the study design of the NAWQA Program in the Southern Florida study unit. 


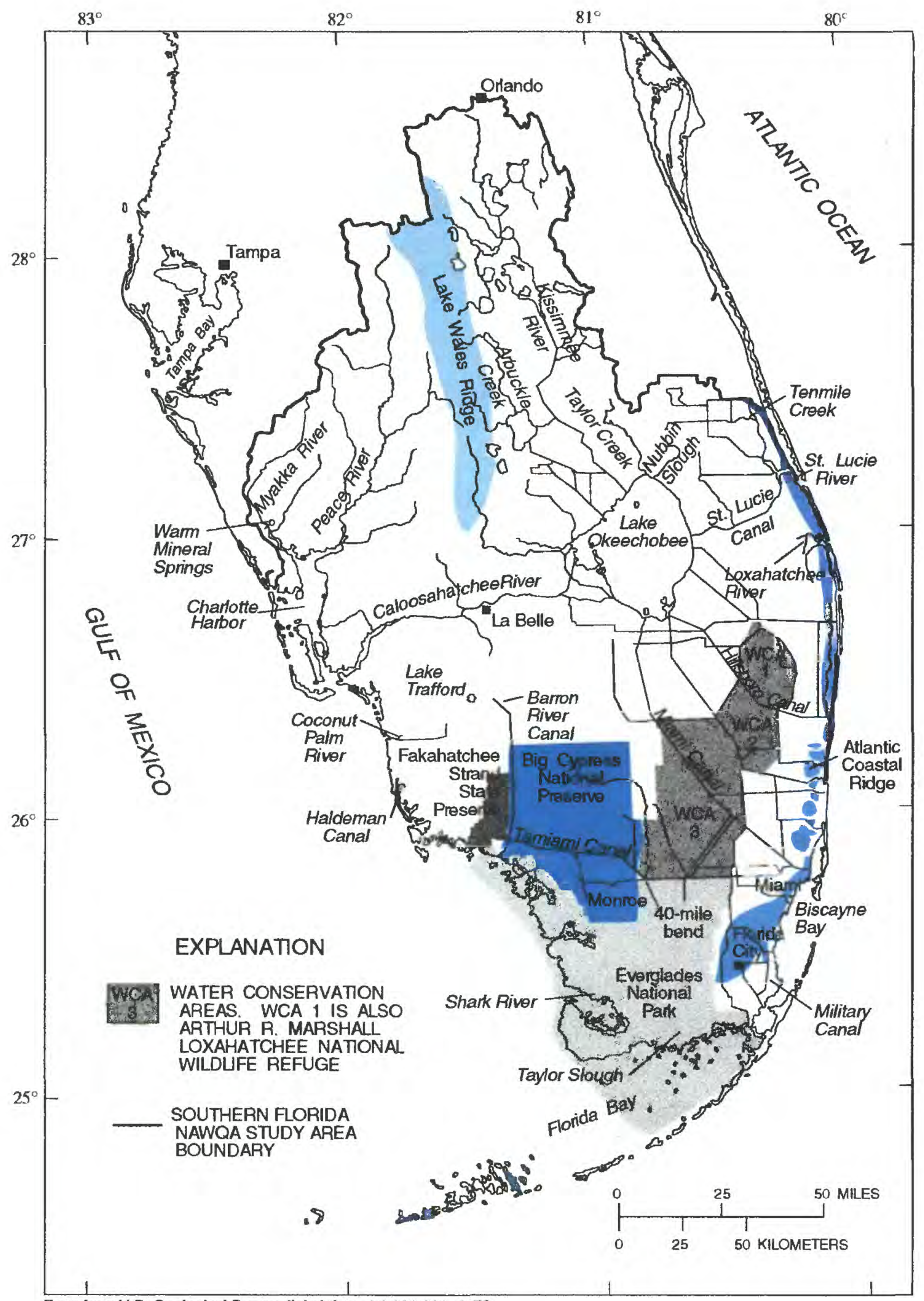

Base from U.S. Geological Survey digital data, 1:2,000,000, 1972

Abers Equal-Area Conic projection

Standard Parallels $29^{\circ} 30^{\circ}$ and $45^{\circ} 30^{\circ}$, central menidian $-83^{\circ} 00^{\circ}$

Figure 2. Major canals, control structures, and other hydrologic features in southern Florida. 


\section{Overview of Surface-Water Quality and Hydrology}

Historically, southern Florida was characterized by large areas of wetlands that were drained by numerous, small coastal streams and several large rivers. The Peace, Myakka, and Caloosahatchee Rivers drained the northwestern parts of the study area and emptied into Charlotte Harbor and the Gulf of Mexico. The Kissimmee River meandered through the central part of the study area and drained into Lake Okeechobee. Most of the land south of Lake Okeechobee was wetlands, including the Everglades and Big Cypress Swamp, where surface water moved slowly by sheetflow to the south and southwest into Florida Bay and the Gulf of Mexico (Davis, 1943). During high-water periods, surface and ground water also spilled and seeped into coastal waters of the Atlantic Ocean, including Biscayne Bay (Parker, 1974). Seasonal flows of freshwater created salinity conditions which supported highly productive estuarine and marine fisheries (Lindall, 1973). Much surface water was lost through evapotranspiration and returned to the system between June and October as rainfall. Water levels in the Everglades fluctuated seasonally over several meters during years with normal rainfall.

Historically, the Everglades was a low-nutrient system where ecosystem productivity was primarily limited by phosphorus. The algae and vascular plants that comprise the marsh ecosystem developed under conditions of low nutrient inputs that are characteristic of pristine rainfall (Davis, 1994). Nutrient inputs from rainfall were so rapidly taken up by the extensive marsh vegetation that nutrient concentrations in surface waters were very low. Nutrient loading to coastal waters was dispersed over broad areas by sheetflow.

Southern Florida has been greatly altered by construction of drainage canals, agriculture, and urban development. Construction of drainage canals began in the 1800's and continued into the 1960's. The St. Lucie and the Caloosahatchee Rivers were connected to Lake Okeechobee; both rivers were enlarged and channelized to carry water to the coast. The Kissimmee River was straightened and channelized to eliminate seasonal flooding on the river's flood plain. Several large canals, including the West Palm Beach, Hillsboro, North New River, and Miami Canals were dug to carry water from Lake Okeechobee to the Atlantic Ocean. A levee was built around the south rim of Lake Okeechobee to prevent spillage of water to the northern Everglades.
Drainage lowered the water table by as much as $2.0 \mathrm{~m}$ and resulted in severe fires, land subsidence, and saltwater intrusion. Subsequently, regional water management efforts were modified and redesigned to lessen these severe effects, to provide flood protection for continued urban and agricultural development, and to ensure an adequate water supply for urban growth. A complex system of canals, levees, pumps, and watercontrol structures was eventually completed.

In the northern Everglades about 324,000 ha was converted to agriculture and designated as the Everglades Agricultural Area (EAA) (fig. 1). Principal crops are sugarcane and winter vegetables. More than 360,000 ha of additional land in the northern Everglades was converted to shallow impoundments (the WCAs) to provide flood protection during the wet season and water supply during the dry season (Cooper and Roy, 1991).

Parts of the southern Everglades and the Big Cypress still retain some of the predevelopment surface-water characteristics. These areas include the ENP and the Big Cypress National Preserve (BCNP). In general, water management has lowered water levels and reduced the frequency and duration of inundation in the Everglades.

Surface-water basins are often ill-defined in parts of southern Florida because of low relief, a lack of distinct drainage divides, and the interconnection of canals. However, for the purposes of this report the Southern Florida study unit is divided into 10 major surface-water basins that differ in their surface-water and land-use characteristics (fig. 1). They are: the Myakka River and Peace River Basin; the Caloosahatchee River Basin; the Big Cypress Basin; the St. Lucie River Basin; the Kissimmee River Basin; Lake Okeechobee; the Everglades; the Everglades Agricultural Area; the East Coast Urban Area; and the Florida Keys. The Florida Keys do not have significant freshwater features and, therefore, are not discussed further in this section of the report.

The Myakka River and Peace River Basins in the northwestern part of the study unit are drained by small rivers that have not been channelized. Water quality in the Myakka River is generally good, and parts of the river have been designated as an Outstanding Florida Water (Livingston, 1991). Natural ground-water inputs are negligible in the Myakka River Basin, and river flow in the dry season is often comprised solely of highly mineralized ground water originating as runoff from irrigated farmland (Livingston, 1991). Rainwater 
runoff is typically acidic and low in total mineral content in this part of Florida. Rangeland and agricultural land use are significant sources of nutrients. There is little urban influence within the watershed. Phosphate mining occurs in the headwaters and both sulfate and phosphorus concentrations are reported to have increased from 1963-85 in surface waters (Hammett, 1990). Water quality in the Peace River is extensively influenced by land use and other human activities. The Peace River has its headwaters in areas with rich phosphate deposits, and the discharge of wastewater by the phosphate mining and fertilizer industries is the most significant influence on water quality in the basin (Lewelling and Wylie, 1993). The annual discharge of the Peace River at Arcadia has shown a significant long-term decline during 1931-85, which is not attributable solely to deficient rainfall (Hammett, 1990) but may be associated with increased pumpage of ground water. The surface-water data indicate that there were long-term increasing trends during 1957-85 for total organic nitrogen, chloride, sulfate, and dissolvedsolids concentrations, and decreasing trends for total phosphorus and orthophosphorus concentrations (Hammett, 1990).

The Caloosahatchee River has been highly modified by channelization and the construction of locks and water-control structures (Livingston and Fernald, 1991), which now control the flow and stage of the river. Water quality in the Caloosahatchee River and its tributaries is influenced primarily by low relief, discharge from Lake Okeechobee, and land use (Drew and Schomer, 1984). During 1978-80, inflow from Lake Okeechobee contributed 55 percent of the total flow in the Caloosahatchee River, 62 percent of the total nitrogen, and 64 percent of the chloride (Miller and others, 1982). The principal types of land use in the eastern part of the basin are cattle, citrus, and vegetable production. Land uses in the western part of the basin are agriculture and urban. Increases in agricultural and urban land uses in the Caloosahatchee River Basin are causing significant changes in water quality.

The Big Cypress Basin consists of numerous sloughs and cypress-dominated strands where water flows southwest and discharges to the Gulf of Mexico. Agriculture is prevalent in the northern part of the basin; Native American lands also are present in the northern part of the basin. In the southern part of the basin, most of the land is undeveloped and publicly owned. Water-quality studies in the 1970's indicated that surface water was uncontaminated in remote und- rained parts of the Big Cypress Basin, but the studies indicated that in other parts of the basin human activities had degraded surface-water quality (McPherson, 1974; Duever, 1984). Nitrogen concentrations were low $(0.03-0.10 \mathrm{mg} / \mathrm{L})$ in this basin compared to concentrations in the urban canals of southern Florida (Klein and others, 1970). There is generally a lack of recent water-quality data in the Big Cypress Basin, although the BCNP began a water-sampling program in the 1980's. Collier County Environmental Services Division (1994) identified some trace elements (chromium, silver, lead, and zinc) in bed-sediment samples at concentrations which are indicative of human influences.

Principal surface-water features in the St. Lucie Basin include wetlands, the St. Lucie Canal, the St. Lucie River, and several smaller streams and canals. Agriculture and wetlands are the two principal types of land cover in the basin; agricultural activities are mainly improved pasture and citrus production. Water quality in the St. Lucie Canal was reported to be similar to water quality in Lake Okeechobee (Parker and others, 1955), which the canal periodically drains. Stormwater inflow influences dissolved-oxygen, suspendedsediment, and nutrient concentrations in canals throughout the basin (Graves and Strom, 1992). Large, sporadic freshwater discharges from canals have had a detrimental effect on biota in the St. Lucie Estuary (Haunert and Startzman, 1985; Haunert, 1988; Steward and others, 1993).

Surface-water chemistry varies spatially and temporally in the Kissimmee River, Lake Okeechobee, and Everglades Basins. The $\mathrm{pH}$ is neutral to slightly basic, and dominant ions are calcium and bicarbonate. Much of the surface water is highly buffered due to contact with periphytic marl, limestone, calcareous sand, or fossilized deposits. WCA-1 and some deep peat ponds are more acidic than surface waters in contact with limestone deposits. Dissolved-solids concentrations and conductivity are often high, and dissolved-oxygen concentrations are typically low. Nutrient retention is high in the marshes of the Everglades, as a result of tight cycling between the plant community and the sediments (Steward and Ornes, 1975). Phosphorus concentrations are low and this element is considered to be the limiting nutrient for plant growth. Total phosphorus concentrations ranged from 0.03 to $0.25 \mathrm{mg} / \mathrm{L}$ during 1973-78 in streams of the Kissimmee River Basin (Federico, 1982) and were generally less than concentrations measured in rainfall. Canal waters in 
agricultural areas of the EAA contain high nutrient concentrations. For example, average concentrations of total phosphorus at 144 sites in the EAA during $1990-92$ ranged from 0.10 to $1.32 \mathrm{mg} / \mathrm{L}$. Water quality in some northern parts of the WCA's are affected by canal waters that drain the EAA and other farm lands. Total nitrogen and phosphorus concentrations in parts of WCA-2 and WCA-3 that receive canal inflows from the EAA are among the highest in southern Florida (Germain, 1994). Interior marshlands of WCA-1 are unaffected by high nutrient concentrations, although peripheral wetlands are affected by canal inflows. Nutrient concentrations in the southern Everglades, including the ENP, are naturally low (Waller, 1975; Waller and Earle, 1975). At nine sites in the interior of the ENP, mean total phosphorus concentrations ranged from 0.01 to $0.06 \mathrm{mg} / \mathrm{L}$ during $1986-93$ and mean total nitrogen concentrations ranged from less than 0.01 to $2.5 \mathrm{mg} / \mathrm{L}$ (Germain, 1994).

The East Coast Urban area includes slightly higher land along the Atlantic Coastal Ridge from Loxahatchee River to the Florida Keys. The East Coast Urban area is home to almost 5 million people and includes high-density residential, commercial and industrial land uses. Water-quality characteristics and nutrient loadings in the basin have been studied in the past (Lutz, 1977a; Dickson, 1980), and the Biscayne Bay SWIM Plan (South Florida Water Management District, 1994a) summarizes results of studies carried out in the southern part of the basin since 1984. Contamination of Biscayne Bay comes principally from the Miami Canal and other canals. Water quality in these urban canals is adversely affected by agricultural and urban runoff, and sewage effluent (Florida Department of Environmental Regulation, 1988). Dissolvedoxygen concentrations are frequently less than 4.0 $\mathrm{mg} / \mathrm{L}$ in the canals and streams in the basin. Nonpoint source pollution from lawn and landscape fertilizer and pesticides, automobile emissions, seepage from landfills, septic tanks, and disposal wells, and construction runoff is significant in the basin.

\section{Issues of Regional Importance to Surface- Water Quality}

Surface water in southern Florida comprises a complex, intensively regulated system of wetlands, lakes, canals, and rivers. Watersheds are not welldefined, and discharge in some streams and canals may cease or be reversed at certain times of the year when back-pumping is used to manage local water levels and regional water supply. The quality of surface water has been and continues to be profoundly influenced by altered patterns of water flow, atmospheric deposition, runoff from agriculture and livestock operations, phosphate mining, urban runoff, municipal wastewater discharge, and other human activities.

\section{Altered Patterns of Water Flow}

Widespread canal construction and drainage manipulation throughout southern Florida have inexorably changed the spatial and temporal patterns of water flow. These hydrologic alterations can have complex, and sometimes subtle but pervasive, effects on water quality.

The Kissimmee River was channelized for flood control between 1962 and 1971, resulting in increased depth, altered patterns of flow, and increased sedimentation. The elimination of flood plains resulted in a lower basin retention time for many constituents and a subsequently higher nutrient input to Lake Okeechobee (Loftin and others, 1990a,b). Restoration of the Kissimmee River to ameliorate the environmental effects of channelization is underway as a joint project of the USACE, the SFWMD, the FGFWFC, and the USFWS (Carroll and Banner, 1991; U.S. Army Corps of Engineers, 1991; South Florida Water Management District, 1991, 1993). A demonstration project involving $19.5 \mathrm{~km}$ of river was initiated in the mid-1980's and the resulting data will be used to guide full-scale restoration efforts. Thus far, the capacity of the wetlands to filter sediment and nutrients has been reestablished in the newly created flood plain adjacent to the demonstration project, and data indicate that dissolvedoxygen concentrations in the river may be increasing (Toth, 1993).

The Caloosahatchee and St. Lucie Canals divert water out of Lake Okeechobee to maintain lake level schedules and prevent floods. This diversion limits the amount and timing of water delivered to the southern Everglades. Levees around the southern edge of the lake further guard against overflow from the lake to the south. Another series of levees and canals in Palm Beach and Dade Counties prevent sheetflow from the Everglades from flowing to the east coast urban area. In the Everglades, water-quality changes can be directly related to the movement of water by canals through the WCA's (Kushlan, 1991; Walker, 1991). The SFWMD regulates the amount of water discharged through 
structures throughout the area. In years of high annual rainfall, this delivery pattern is problematic for the ENP, and naturally high water levels in the Park are even higher (South Florida Water Management District, 1995). Moreover, drawdown and reflooding of marshlands in the WCA's may increase the release of inorganic phosphorus (Gleason, 1974; Swift and Nicholas, 1987; Worth, 1988).

The construction of canals in southern Florida has resulted in a much greater transport of nutrients, suspended sediment, trace elements, and other contaminants in water than occurred when most water moved overland to the coasts by sheetflow (Carter and others, 1973). Canals in the northern Everglades were constructed to drain water and to create agricultural land (the EAA). Intensive agriculture in this area contributes significant amounts of nutrients to surface waters in southern Florida. Soil subsidence (due to physical, chemical, and microbiological processes) is a direct result of drainage and exposure of Everglades soil to air, and is a severe threat to agriculture in the EAA (Science Sub-Group, 1994).

Demand for water in the East Coast Urban area is out of phase with the natural seasonal hydrologic cycle, necessitating the artificial movement of water. Balancing water needs for the ENP with needs for the urban population (about 5 million) of the East Coast Urban area (Miami, West Palm Beach, Boca Raton, Ft. Lauderdale) is critical to the region. Although rainfall provides most of the recharge to ground water, which in turn provides most of the drinking-water supply, water carried into the area by canals supplements this recharge during the dry season. The South Dade Conveyance System provides a mandated supply of water to the ENP and also supplies water to other southern Dade County canals to prevent saltwater intrusion (Cooper and Lane, 1987). The Lower East Coast Regional Water Supply Plan, when fully implemented, will aid in achieving the critical balance (South Florida Water Management District, 1995).

When ecosystem restoration is implemented in southern Florida, patterns of water flow in many areas will again be changed-this time back toward historical patterns (South Florida Water Management District, 1995). More water will be moved through historical flow paths, such as Shark River and Taylor Sloughs. Water quality, however, could be poor (contain high concentrations of nutrients, pesticides, and sediment) if water is diverted directly from agricultural or urban lands where fertilizers and pesticides are intensively applied. Redirection of water to the Everglades Protection Area will be beneficial to the ecosystem only if the water quality is good and concentrations of nutrients, pesticides, and other contaminants are low. Projects are underway to evaluate appropriate water-quality standards for waters entering the Everglades and to implement treatment of stormwater runoff from the EAA in Stormwater Treatment Areas so that surface-water inflows will cause no imbalance in Everglades flora and fauna (South Florida Water Management District, 1995).

\section{Relation of Atmospheric Deposition to Surface- Water Quality}

The atmosphere is recognized as a principal pathway by which nutrients, pesticides, and other organic and inorganic compounds are transported and deposited in areas frequently far removed from their sources (Majewski and Capel, 1995). The chemical composition of rainfall is influenced by natural factors such as fires, oceanic sources of sea salts, and the frequency of thundershowers which produce oxides of nitrogen; and by human activities such as agriculture, application of lawn-care chemicals, burning of fossil fuels in powerplants and vehicles, and waste processing.

Atmospheric deposition is a significant source of many contaminants detected in surface water in southern Florida, including nutrients, pesticides, PCB's, and mercury. Bulk precipitation (dry-fall and rainfall) is a major source of nutrients in southern Florida surface waters (Waller, 1975). However, accurate measurements of atmospheric concentrations of nutrients are subject to a number of complicating factors. Consequently, estimates of atmospheric deposition of nutrients may vary significantly with location, date, and method of collection (Irwin and Kirkland, 1980; Allen and Sutton, 1990; Baker, 1991; South Florida Water Management District, 1992b; Peters and Reese, 1994). The SFWMD (1992b) has a network of 273 rainfallquantity stations, 4 long-term (10-14 years) rainfallquality stations, and several other short-term rainfallquality stations. During 1974-86, most samples collected were bulk precipitation; after May 1986, separate samples of wet and dry atmospheric precipitation were collected (South Florida Water Management District, 1992b). The mean concentration of phosphorus during $1979-89$ ranged from 0.03 to $0.11 \mathrm{mg} / \mathrm{L}$; concentrations were highest at sites that were affected by airborne particles from soil, agricultural activities, and fires (South Florida Water Management District, 
Table 1. Average nutrient concentrations in precipitation at selected sites in Florida, 1990-92

[South Florida Water Management District sites sampled during 1990-92.

(See Germain, 1994); mg/L, milligrams per liter]

\begin{tabular}{|c|c|c|c|c|}
\hline \multirow[b]{2}{*}{ Site } & \multicolumn{2}{|c|}{ Total nitrogen } & \multicolumn{2}{|c|}{ Total phosphorus } \\
\hline & $\begin{array}{c}\text { Average } \\
\text { (mg/L) }\end{array}$ & $\begin{array}{l}\text { Range, } \\
\text { (mg/L) }\end{array}$ & $\begin{array}{c}\text { Average } \\
\text { (mg/L) }\end{array}$ & $\begin{array}{l}\text { Range, } \\
\text { (mg/L) }\end{array}$ \\
\hline Kissimmee River at S65A & 1.01 & $<0.50-5.43$ & 0.065 & $<0.004-0.792$ \\
\hline $\begin{array}{l}\text { Lake Okeechobee Field } \\
\text { Station }\end{array}$ & 1.11 & $0.52-11.70$ & 0.026 & $<0.004-0.452$ \\
\hline $\begin{array}{l}\text { Lake Okeechobee, southeast } \\
\text { shore }\end{array}$ & 0.98 & $0.56-4.59$ & 0.058 & $<0.004-0.424$ \\
\hline Pump Station S-7 & 1.07 & $0.54-2.60$ & 0.042 & $<0.004-0.379$ \\
\hline $\begin{array}{l}\text { Everglades Nutrient Removal } \\
\text { Project }\end{array}$ & 0.77 & $0.54-2.04$ & 0.012 & $<0.004-0.112$ \\
\hline $\begin{array}{l}\text { Water Conservation- Area } \\
\text { 3A near Pump Station S-140 }\end{array}$ & 1.45 & $<0.50-7.18$ & 0.098 & $<0.004-1.135$ \\
\hline $\begin{array}{l}\text { Everglades National Park } \\
\text { Research Center }\end{array}$ & 1.21 & $0.51-21.40$ & 0.014 & $<0.004-0.203$ \\
\hline
\end{tabular}

1992b). During 1990-92, concentrations of nitrogen and phosphorus were determined in wet and dry atmospheric precipitation collected at seven sites in southern Florida (table 1) following NADP protocols (Stansland and others, 1983; Peden, 1986; Bigelow and Dossett, 1989), except that samples were collected every 2 weeks. After March 1992, samples were collected weekly to satisfy NADP protocols. Average phosphorus concentrations ranged from 0.012 to 0.098 $\mathrm{mg} / \mathrm{L}$, and average nitrogen concentrations ranged from 0.77 to $1.45 \mathrm{mg} / \mathrm{L}$.

Estimates of atmospheric deposition rates (loading) of nitrogen and phosphorus are available for the southern Florida study area and other parts of Florida (table 2). Total phosphorus loading from precipitation in WCA-1, WCA-2, and WCA-3 was estimated to be 54,56 , and $56\left(\mathrm{~kg} / \mathrm{km}^{2}\right) / \mathrm{yr}$, respectively (South Florida Water Management District, 1992a). The SFWMD (1992a) estimated that rainfall contributed 40 percent of the total phosphorus input to the WCAs during 1979-88. Efforts continue to refine estimates of the relative contribution to nutrient loading from atmospheric deposition, as well as from the other nonpoint sources.

Several national studies of atmospheric sources of pesticides include data from sites in southern Florida. At least 10 organochlorine insecticides and at least 5 organophosphorus insecticides have been detected in air, rain, or fog at sample sites in Florida (Majewski and Capel, 1995). Dieldrin, alpha and gamma $\mathrm{HCH}$, diazinon, and malathion are all used on cropland in southern Florida and were all detected in air samples collected at sites in southern Florida (Majewski and
Capel, 1995). Aldrin was detected in air samples collected in Florida City (Tabor, 1965). Several pesticides, including chlordane, oxychlordane, parathion, and methylparathion, were detected in air samples collected in Miami in 1975 (Kutz and others, 1976). The relatively wide distribution of PCBs in Florida is most likely a result of volatilization and transport by aerosols and fallout with dust or rain (Pfeuffer, 1991).

Vast amounts of mercury continually enter the atmosphere from natural sources, vaporized from the Earth's crust and mobilized from marine sediments. Burning coal and other industrial activities add to the global atmospheric mercury burden. Most mercury entering the aquatic habitat from the atmosphere is primarily in the inorganic form, which is only moderately toxic and has a short retention time. Under acidic conditions, anaerobic bacteria in many aquatic systems can convert inorganic mercury to highly toxic methyl mercury. Mercury in southern Florida is principally of interest because of its effects on the biota; consequently, mercury is discussed in greater detail in the section of this report on issues of regional importance to aquatic ecology.

\section{Nutrient Enrichment}

Human activities are the principal source of nutrient inputs to surface water in southern Florida. Application of fertilizers and other agricultural activities in many parts of the study unit have significantly increased nutrient input to surface waters above historical levels. For example, high nutrient concentrations in the Kissimmee River primarily are attributable to 
Table 2. Estimated annual atmospheric loading of nitrogen and phosphorus at selected sites in Florida [SFWMD, South Florida Water Management District; SWIM, Surface Water Improvement and Management; --, not available]

\begin{tabular}{|c|c|c|c|c|c|}
\hline \multirow[b]{2}{*}{. Description of data } & \multirow[b]{2}{*}{ Source of data } & \multicolumn{4}{|c|}{$\begin{array}{l}\text { Atmospheric loading, } \\
\text { in kilograms per square kilometer per year }\end{array}$} \\
\hline & & $\begin{array}{c}\text { Total } \\
\text { phosphorus }\end{array}$ & $\begin{array}{c}\text { Total } \\
\text { nitrogen }\end{array}$ & $\begin{array}{c}\text { Nitrogen, } \\
\text { ammonia } \\
\text { plus nitrate }\end{array}$ & $\begin{array}{l}\text { Nitrogen, } \\
\text { nitrate }\end{array}$ \\
\hline Bulk precipitation; statewide'; collected during 1970’s & Irwin and Kirkland (1980) & 130 & 1,400 & -- & - \\
\hline Bulk precipitation; south Florida & SFWMD SWIM Program (1992b) & 65 & - & -- & - \\
\hline Bulk precipitation; three Water Conservation Areas $^{2}$ & SFWMD SWIM Program (1992b) & 55 & - & -- & -- \\
\hline $\begin{array}{l}\text { Bulk precipitation; uncontaminated areas of south } \\
\text { Florida }\end{array}$ & SFWMD SWIM Program (1992b) & 39 & -. & - & - \\
\hline $\begin{array}{l}\text { Wet }+ \text { dry precipitation; Cary Forest northeast of } \\
\text { Gainesville; } 1988-89\end{array}$ & Allen and Sutton (1990) & 15 & 660 & -- & - \\
\hline $\begin{array}{l}\text { Wetfall only; five Florida sites; 1993; volume- } \\
\text { weighted }\end{array}$ & $\begin{array}{l}\text { National Atmospheric Deposition } \\
\text { Program (1994) }\end{array}$ & - & -- & 330 & -- \\
\hline $\begin{array}{l}\text { Wetfall only; four Tampa sites; 8-10 events during } \\
\text { 1975-80 }\end{array}$ & Lopez and Giovanelli (1984) & 250 & 1,300 & - & - \\
\hline $\begin{array}{l}\text { Wetfall only; not volume-weighted;average of seven } \\
\text { sites in south Florida }\end{array}$ & Germain (1994) & 59 & 1,400 & -- & 330 \\
\hline $\begin{array}{l}\text { Wetfall only; quantity estimated from rain gage at } \\
\text { Okeechobee Field Station; 04/92-04/93 }\end{array}$ & Computed from SFWMD data & 20 & 1,800 & - & -- \\
\hline $\begin{array}{l}\text { Wetfall only; quantity estimated from rain gage at } \\
\text { Structure S-65A; 04/92-04/94 }\end{array}$ & Computed from SFWMD data & 42 & 1,400 & -- & -- \\
\hline $\begin{array}{l}\text { Wetfall only; quantity estimated from rain gage at } \\
\text { Structure S-7; 05/92-05/94 }\end{array}$ & Computed from SFWMD data & 18 & 1,300 & -- & - \\
\hline
\end{tabular}

'Based on 130 centimeters average annual precipitation.

${ }^{2}$ Based on 118 centimeters average annual precipitation.

runoff from improved pasture and dairy operations. Nutrient concentrations in the Taylor Creek, Nubbin Slough, Lower Kissimmee River, and Arbuckle Creek subbasins (fig. 2) are influenced by feedlot and cattle operations (Germain, 1994). Nutrient concentrations in the St. Lucie River Basin during 1976-77 were highest during periods of highest discharge and were influenced by agricultural runoff (Federico, 1983). The range of average nitrogen concentrations was 1.38 to $1.58 \mathrm{mg} / \mathrm{L}$ and the range of average phosphorus concentrations was 0.11 to $0.26 \mathrm{mg} / \mathrm{L}$ in surface waters during 1976-77 (Federico, 1983).

Urban land use is the most important influence on surface-water quality in parts of the study unit. Urban stormwater runoff from Fort Myers and La Belle contributes significant amounts of nutrients to the Caloosahatchee River (Environmental Science and Engineering, 1977). Effluent from wastewater treatment plants in Lakeland, Winter Haven, and Bartow contributes nitrogen to the streams of the Peace River Basin (Fraser, 1991; Irwin and Swihart, 1993). Total nitrogen concentrations in the Peace River, which often exceed $1.0 \mathrm{mg} / \mathrm{L}$ (German and Schiffer, 1988), are also influenced by agricultural runoff and the discharge of citrus processing operations. In at least one part of the study unit, natural sources of nutrients are important.
The Peace River is naturally enriched with phosphorus, because the river flows through phosphate deposits. However, mining activities in the basin accelerate the rate at which phosphorus enters surface waters. The Peace River has the second highest phosphate concentration of all of Florida's rivers. During 1974-82, total phosphorus concentrations commonly exceeded $0.1 \mathrm{mg} / \mathrm{L}$ (German and Schiffer, 1988).

Lake Okeechobee is naturally eutrophic, but due to human influence, the lake has become hypereutrophic. The lake acts as a sink for nutrients, which are retained in the organic bottom sediment. The concentration of total phosphorus almost doubled, from $49 \mu \mathrm{g} / \mathrm{L}$ in 1973 to $98 \mu \mathrm{g} / \mathrm{L}$ in 1984 (Aumen, 1995). More than 50 percent of the phosphorus and 30 percent of the nitrogen inputs to the lake are from the Kissimmee River and from Taylor Creek/Nubbin Slough (Federico and others, 1981; Jones, 1987; Janus and others, 1990). Also, nutrient-laden waters discharged from the EAA were formerly channeled to Lake Okeechobee (Dickson and others, 1978). In recent years, however, efforts have been made to keep these nutrient-laden waters out of Lake Okeechobee. As a result, back pumping of water from the EAA to the lake has decreased, but more of this nutrient-enriched water has entered the WCAs (Lutz, 1977b). Total nitrogen concentrations at sites in 
the northern Everglades influenced by the EAA are now among the highest in southern Florida. Mean total nitrogen concentrations ranged from 1.10 to $5.60 \mathrm{mg} / \mathrm{L}$ in the WCAs during the period of record, and mean total phosphorus concentrations ranged from 0.01 to $0.91 \mu \mathrm{g} / \mathrm{L}$ (Germain, 1994). Estimates of phosphorus concentrations flowing into and out of the WCAs indicates that the WCAs are efficient at assimilating the phosphorus loads (South Florida Water Management District, 1992a). Phosphorus concentrations in water in WCA marshlands generally follow a gradient of high to low from the input point to interior marsh locations (Whalen and others, 1992; Reddy and others, 1993; Urban and others, 1993; Davis, 1994). This pattern is most conspicuous in WCA-2, where water from canals flows into the interior marshes. In WCA-1, land surface elevation is greater in the marsh interior than along the perimeter; therefore, water tends to flow along the periphery of the marsh instead of through it.

A significant component of ongoing southern Florida ecosystem restoration efforts is the reduction of phosphorus loading to WCA-1 and the ENP (South Florida Water Management District, 1995). The SFWMD and the FDEP are conducting research to define acceptable nutrient concentrations for the protection and restoration of the Everglades, with the emphasis on phosphorus concentrations. This research began in WCA-2 in 1994 and has several components. Data are being collected along a nutrient gradient in the marsh where sawgrass has been replaced by cattails.

Data are also being collected from a series of "dosing chambers" placed in the marsh which are treated with known amounts of phosphorus and then monitored for changes in vegetation. In addition, State and Federal agencies are jointly sponsoring dosing threshold research being conducted by Florida International University.

Development of a nutrient budget for southern Florida is a goal of the SFWMD, as well as other agencies involved in ecosystem restoration in the region. Estimates of nutrient inputs and outflows is an initial step in this complex process (Puckett, 1994). In this report, the relative contributions of various point and nonpoint sources of phosphorus (fig. 3 ) and nitrogen (fig. 4) were estimated in nine surface-water basins in the Southern Florida study unit (see Appendix for data sources and computation methods). Fertilizer and manure from agriculture account for much of the nutrient inputs. Fertilizer is the dominant source of phosphorus in eight basins and of nitrogen in at least five basins. Canal inflow is the largest source of phosphorus input to Lake Okeechobee and the second largest source of nitrogen input to the lake, after atmospheric deposition. Atmospheric sources of nitrogen contribute more than about 20 percent of the total nitrogen input to all basins and are the dominant source of input to Lake Okeechobee and the Everglades.

The total nutrient input from all sources was estimated for the nine southern Florida surface-water basins (table 3). Total phosphorus inputs ranged from $100\left(\mathrm{~kg} / \mathrm{km}^{2}\right) / \mathrm{yr}$ in Lake Okeechobee to $4,800(\mathrm{~kg} /$ $\left.\mathrm{km}^{2}\right) / \mathrm{yr}$ in the EAA. Total nitrogen inputs ranged from $2,900\left(\mathrm{~kg} / \mathrm{km}^{2}\right) / \mathrm{yr}$ in the Everglades to $9,200\left(\mathrm{~kg} / \mathrm{km}^{2}\right) /$ $\mathrm{yr}$ in the EAA.

Estimates of nutrient loads in selected canal and river outflows in southern Florida were calculated for this report from data collected by the SFWMD and the USGS (figs. 5-6). Annual phosphorus loads from the Peace River (fig. 5) are the highest in the study unit; annual phosphorus loads from the Caloosahatchee River and the major Palm Beach canals are also high, compared to loads in other parts of southern Florida. Estimated annual loads of phosphorus from the S-12 water-control structures and parts of the Big Cypress Basin (Tamiami Trail; 40-Mile Bend to Monroe) are low compared with estimated loads in the northern part of the study unit (fig. 5). Annual nitrogen loads (fig. 6) were highest in outflows from the Caloosahatchee River Basin and the major Palm Beach canals. Nitrogen loads in outflows from parts of the Big Cypress subbasin (Tamiami Trail; 40-Mile Bend to Monroe) were lower than estimated loads to the north.

\section{Pesticides and Other Organic Compounds in Water and Sediment}

Pesticides are widely used in southern Florida for agriculture; for maintenance of highway right-of-ways, domestic lawns, and golf courses; and for control of aquatic weeds and mosquitoes. Application to agricultural crops constitutes the major use of pesticides in southern Florida, where citrus, sugar cane, and vegetables are the principal crops. Petroleum distillates and ethion are the principal insecticides (on a weight basis) used on citrus crops. Methomyl is the main insecticide used on vegetables (corn, peppers, and tomatoes), and ethoprop and phorate are the main insecticides used on sugarcane. Chlorpyrifos is another widely applied insecticide, with approximately equal amounts used on vegetables, citrus, domestic lawns, and golf courses. 


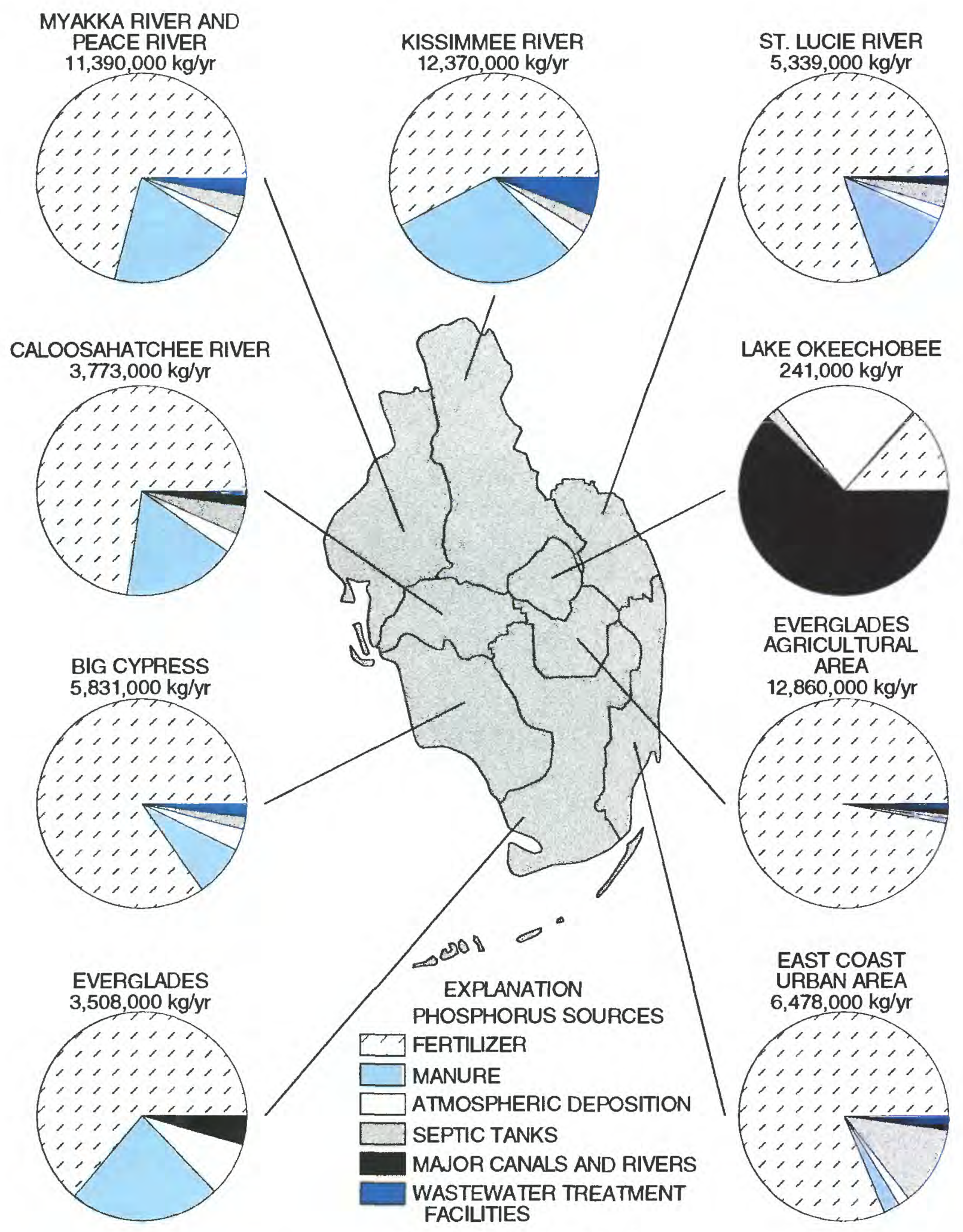

[kg/yr, kilograms per year]

Figure 3. Estimated phosphorus loading from point and nonpoint sources in surface-water basins in southern Florida (see appendix for information on data sources and computational methods). 


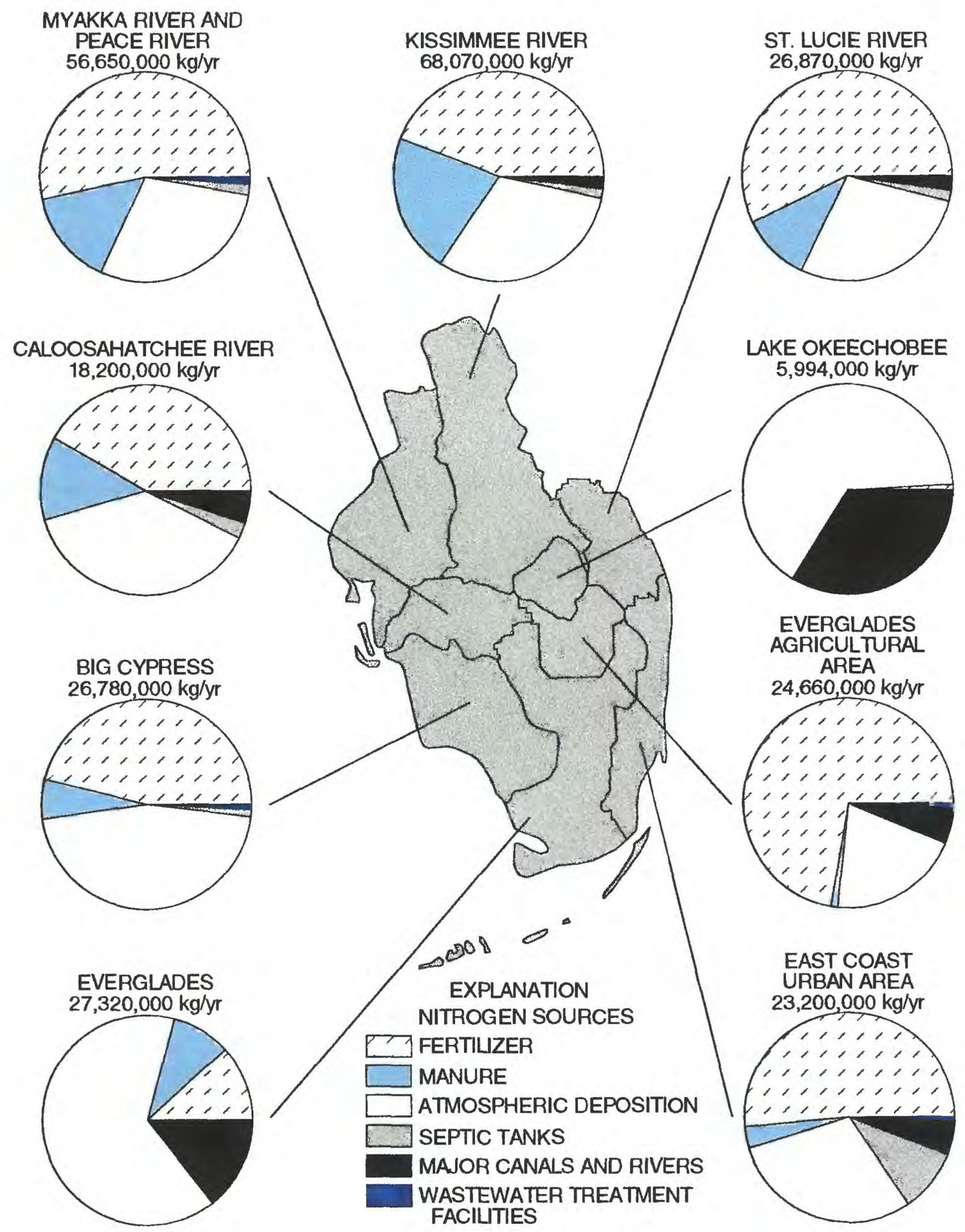

[kg/yr, kilograms per year]

Figure 4. Estimated nitrogen loading from point and nonpoint sources in surface-water basins in southern Florida (see appendix for information on data sources and computational methods). 
Table 3. Estimates of nitrogen and phosphorus inputs to drainage basins in the Southern Florida NAWQA study unit

\begin{tabular}{lccccc}
\hline \multicolumn{1}{c}{ Basin } & $\begin{array}{c}\text { Total } \\
\text { nitrogen } \\
\text { input } \\
\text { (kilograms } \\
\text { per year) }\end{array}$ & $\begin{array}{c}\text { Total } \\
\text { phosphorus } \\
\text { input } \\
\text { (kilograms } \\
\text { per year) }\end{array}$ & $\begin{array}{c}\text { Basin } \\
\text { area } \\
\text { (hectares) }\end{array}$ & $\begin{array}{c}\text { Nitrogen } \\
\text { input } \\
\text { (kilograms } \\
\text { per hectare } \\
\text { per year) }\end{array}$ & $\begin{array}{c}\text { Phosphorus } \\
\text { input, } \\
\text { (kilograms } \\
\text { per hectare } \\
\text { per year) }\end{array}$ \\
\hline Big Cypress & $26,800,000$ & $5,830,000$ & 649,000 & 41 & 9 \\
Caloosahatchee River & $18,200,000$ & $3,770,000$ & 349,000 & 52 & 11 \\
East Coast Urban Area & $23,200,000$ & $6,480,000$ & 412,000 & 56 & 16 \\
Everglades & $27,300,000$ & $3,510,000$ & 935,000 & 29 & 4 \\
Everglades Agricultural Area & $24,700,000$ & $12,900,000$ & 270,000 & 91 & 48 \\
Kissimmee River & $68,100,000$ & $12,400,000$ & $1,060,000$ & 64 & 12 \\
Lake Okeechobee & $6,000,000$ & 241,000 & 181,000 & 33 & 1 \\
St. Lucie River & $26,900,000$ & $5,340,000$ & 351,000 & 77 & 15 \\
Myakka River and Peace River & $56,700,000$ & $11,400,000$ & 840,000 & 67 & 14 \\
\hline
\end{tabular}

Atrazine, the major herbicide used in southern Florida, is applied primarily on sugarcane, but also on vegetables. Bromacil, diuron, glyphosate, and simazine are all used on citrus crops, and monosodium methanearsonate (MSMA) is the main herbicide used on golf courses. Agricultural application also leads in the use of fungicides. Sulfur and copper hydroxides are the most frequently applied fungicides on citrus crops, and EBDCs (ethylenebisdithiocarbamates) and chlorothalonil are used mostly frequently on vegetables (primarily tomatoes). Fenamiphos is the major nematocide used, and it is applied primarily on golf courses. Methyl bromide and chloropicrin are the major soil fumigants used, and they are used exclusively on tomatoes and peppers (R.J. Miles and C.J. Pfeuffer, SFWMD, written commun., 1994).

The occurrence, distribution, and fate of pesticides has been a long-standing water-quality concern in southern Florida. In the late 1960's and early 1970's, pesticides were detected in water, bed sediment, and fish in the Everglades (Kolipinski and Higer, 1969; Kolipinski and others, 1971; McPherson, 1973). Other studies reported relatively high concentrations of chlorinated hydrocarbons in southern Lake Okeechobee, Hillsboro Canal, and Miami Canal (Pfeuffer, 1985). In the early 1970 's, PCBs were determined to be widely distributed in the southern Florida environment (Klein and others, 1970). Early studies of pesticides in southwestern Florida indicated few detections in water, but more frequent detections in bed sediment (McPherson 1969; U.S. Environmental Protection Agency, 1972; Carter and others, 1973). For example, in the Big Cypress Basin pesticides were detected in low concentrations in water samples and at high concentrations in bed sediment (Klein and others, 1970). DDT and its degradation products were the most commonly detected compounds in bed sediment during 1969-70; the mean reported concentration of DDT in the BCNP was $5.1 \mu \mathrm{g} / \mathrm{kg}$. Soil samples collected in the eastern part of the ENP indicated that concentrations of PCBs and DDT were very low within the ENP, although concentrations in soil samples from agricultural fields within $2 \mathrm{~km}$ of the ENP boundary were two orders of magnitude higher (Requejo and others, 1979).

The SFWMD initiated a district-wide pesticide monitoring program in 1984. During 1984-90, atrazine was the only pesticide consistently detected in surfacewater samples; most of the detections were between 0.1 and $1.0 \mu \mathrm{g} / \mathrm{L}$. The greatest frequency of atrazine detections was along the south shore of Lake Okeechobee, and in canals draining the EAA, indicating that atrazine use may be significant in areas adjacent to these sites (Pfeuffer, 1991). Atrazine concentrations in basins within the EAA are frequently above the State criteria (South Florida Water Management District, 1995).Residues of DDD and DDE were detected in bed-sediment samples collected at these sites, as well as in canals adjacent to agricultural land to the east of the ENP. Detectable concentrations of ethion and DDT were consistently measured in areas adjacent to citrus agriculture. An ongoing SFWMD pesticide monitoring program continues to detect herbicides, including atrazine, ametryn, bromacil, and simazine, and the insecticide endosulfan (South Florida Water Management District, 1995). 


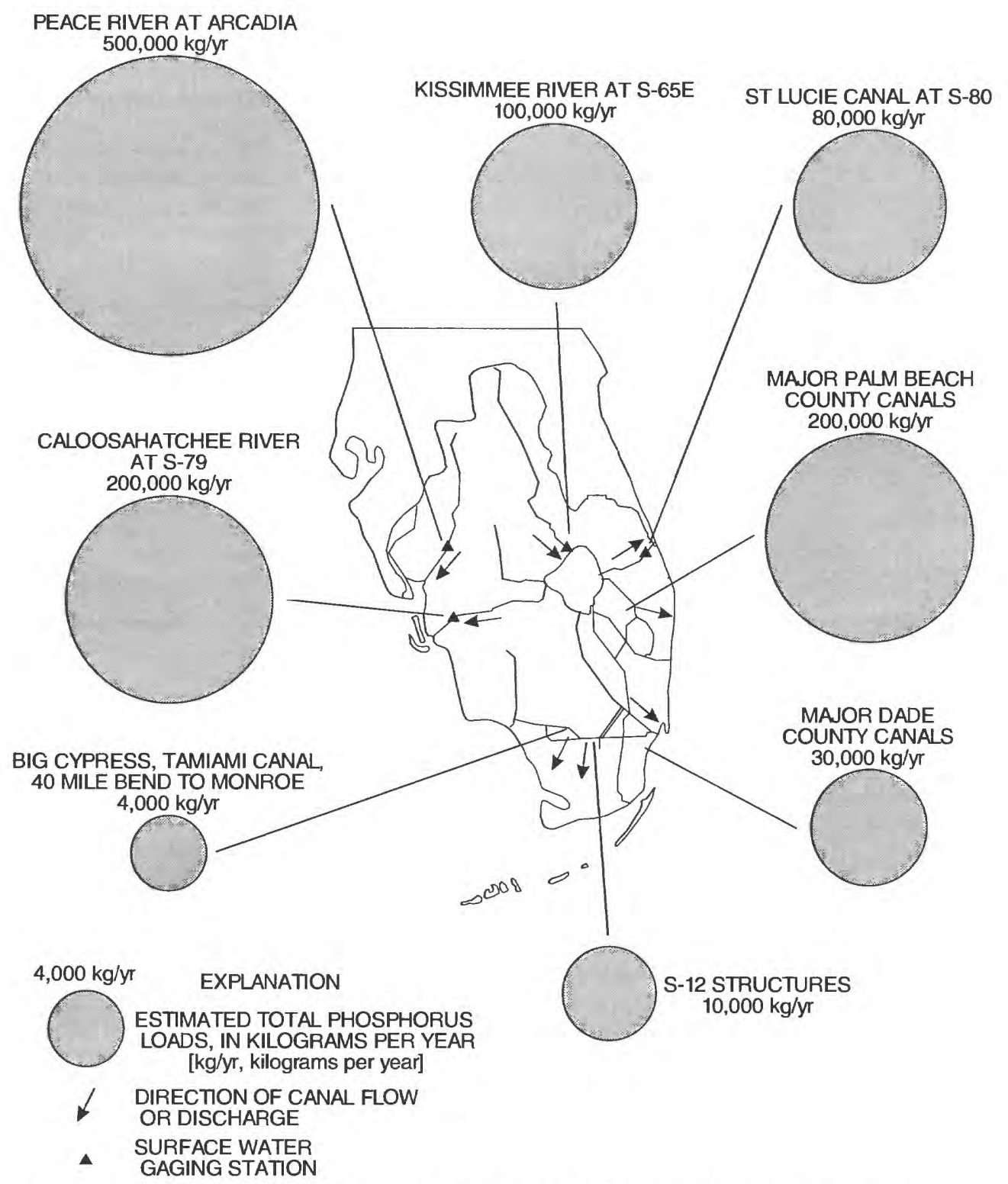

Figure 5. Estimated total phosphorus loads for selected canal and river outflows from surface-water basins in southern Florida.

In the Barron River Canal, d-BHC (benzene hexachloride) $(99 \mu \mathrm{g} / \mathrm{kg})$ and aldrin $(1.3 \mu \mathrm{g} / \mathrm{kg})$ were detected in bed sediment samples during 1989-91 (Collier County Environmental Services Division, 1994). Stream-bed sediment has been sampled repeatedly since 1990 in Collier County; eight organochlorine pesticides have been detected at 15 of 26 sites sampled. Concentrations of chlordane in the Coconut Palm River, d-BHC in the Barron River Canal, and endosulfan sulfate in the Haldeman Canal were the highest concentrations of these pesticides in bed sediment reported to date in Florida (Collier County Environmental Services Division, 1994).

In the Caloosahatchee River, several agricultural pesticides (aldrin, dieldrin, DDT, and chlordane) have been detected at concentrations exceeding the Florida Water Quality Standards (Drew and Schomer, 1984). Urban stormwater runoff from $\mathrm{Ft}$. Myers and LaBelle also contributes pesticides to the Caloosahatchee River, which is a primary or secondary source of drinking water for basin residents (Environmental Science and Engineering, Inc., 1977). 


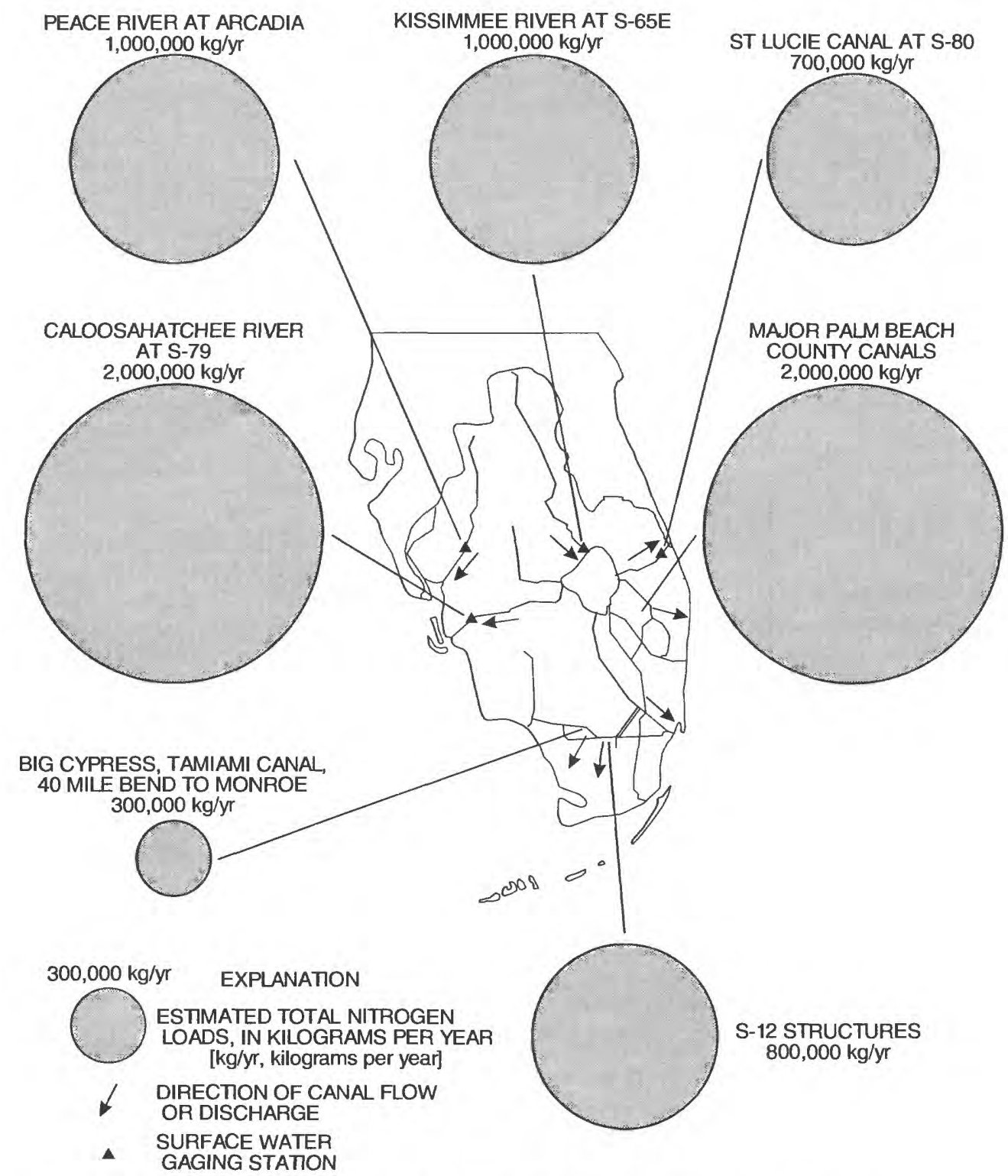

Figure 6. Estimated total nitrogen loads for selected canal and river outflows from surface-water basins in southern Florida.

In the East Coast Urban Basin, pesticides associated with citrus farming have been detected in the Ten Mile Creek subbasin. Bromacil, metalaxyl, simazine, diazinon, ethion, malathion, and endosulfan sulfate are among the 14 pesticides detected in water samples during 1993-95 (Graves and Strom, 1995a,b). Biscayne Bay has a significant pesticide input due to agricultural land use ( 24 percent of the watershed). An estimated 200,000 $\mathrm{kg}$ of 35 common pesticides are used per year in the basin. Among the pesticides of greatest concern are atrazine, 2,4-D, endosulfan, and chlorpyrifos (Pait and others, 1992). Contaminants of greatest concern in the East Coast Urban area are trace elements, PCBs, PAHs, and pesticides. Endosulfan degradation products have been detected at five water-control structures in south Dade County (C.J. Miles and R.J. Pfeuffer, SFWMD, written commun., 1995), occasionally at concentrations which exceeded the Florida surface-water-quality standard for endosulfan $(0.056 \mu \mathrm{g} / \mathrm{L})$ (Florida Department of Environmental Protection, 1995). 
In the ENP aldrin, heptachlor, and toxaphene were detected in surface-water samples collected during 1980 (Pfeuffer, 1985). Endosulfan and endosulfan oxide residues have been detected in water samples collected at all water control structures in south Dade County since 1987 (C.J. Miles and R.J. Pfeuffer, SFWMD, written commun., 1995). Maximum concentrations of endosulfan $(0.03-0.29 \mu \mathrm{g} / \mathrm{L})$ occurred in late winter and early spring, and exceeded the FDEP standard for Class III waters $(0.056 \mu \mathrm{g} / \mathrm{L})$ (Florida Department of Environmental Protection, 1995) on more than one sampling date. Concentrations of DDD and/or DDE in bed sediment in the ENP during August 1984-July 1988 were lower than those routinely measured during previous SFWMD monitoring (Pfeuffer, 1991).

Monitoring of pesticides in water and bed sediment has been carried out for many years in southern Florida, but there is little information or understanding of processes of pesticide transport, degradation, uptake, and biological effects. Recent studies suggest that there are widespread effects of low-level concentrations of pesticides and other organic compounds on wildlife reproduction and human health (Colborn and others, 1993). More information is needed before the degree that these contaminants are affecting the southern Florida ecosystem can be assessed.

\section{Radioactivity}

The Peace River and Myakka River Basins have significant inputs of radionuclides from the naturally high radioactivity associated with phosphate deposits that occur within the basins and from phosphate mining and processing. In the upper Peace River Basin, much of the radioactivity tends to be transported on particles such as clays and other fines that are washed downstream, whereas in the lower part of the basin ground water introduces significant amounts of soluble radium-226 (Miller and others, 1990). Occasionally, dikes that contain waste clays (slimes) from phosphate mines rupture and release large volumes of these fines into the Peace River. Miller and Morris (1981) reported 22 slime-pond spills into the Peace River between 1942 and 1980 . These accidental spills have the potential to release enough ion-exchangeable radium-226 to equal the annual load of natural radium-226 transported by the river (Miller and McPherson, 1987). Radium-226 concentrations in estuarine water in Charlotte Harbor are approximately an order of magnitude higher than for water in many other estuaries in the Nation, due to the inflow of radium-226 rich ground water. Radium226 and radon- 222 have been used to identify areas of significant ground-water inflow; radium-226 has been used as a natural tracer to estimate the rate of groundwater inflow into the Charlotte Harbor estuary (Miller and others, 1990). Radium-226 radioactivity approximately doubled in the Myakka River below where Warm Mineral Springs flows into the river (Miller and others, 1990). Disposal of the highly concentrated reject water from reverse osmosis plants in coastal areas of southwestern Florida is another potentially important source of radioactivity in surface water as the treatment of saline water for public consumption becomes more common.

\section{GROUND-WATER QUALITY IN SOUTHERN FLORIDA}

Ground water is the most important drinking-water resource in southern Florida. About 5.5 million people depend on ground water as a primary source of drinking water, and about 4.7 million of those people use water from wells less than $60 \mathrm{~m}$ deep. Ground water in southern Florida is vulnerable to contamination because of its close proximity to the surface.The focus of the NAWQA Program's study of ground-water quality in southern Florida is on assessing human influences on shallow ground water.

\section{Overview of Ground-Water Quality and Hydrogeology}

The hydrogeologic features of southern Florida's principal aquifers have been described previously by Parker and others (1955) and many other authors. The principal aquifers in southern Florida are the Biscayne aquifer, the surficial and intermediate aquifer systems, and the Floridan aquifer system. Waters in all the aquifer systems in the study unit are primarily a calcium bicarbonate type, mostly because shell, limestone, or dolomite is predominant in the aquifers. The waters are generally considered to be hard to very hard.

The Biscayne aquifer is a surficial aquifer that underlies all of Dade, Broward, and parts of Palm Beach and Monroe Counties and consists of a very permeable interbedded limestone and sandstone. The Biscayne aquifer has a water table that is close to the land surface and has a high recharge rate of approximately $98 \mathrm{~cm} / \mathrm{yr}$. The Biscayne aquifer is aerobic in 
the upper $9 \mathrm{~m}$ or so, and anaerobic (reducing) in the deeper parts. Waters from the Biscayne aquifer are used extensively for public supply. Pumping of the aquifer is managed carefully to minimize saltwater intrusion. Concentrations of most water-quality constituents in the aquifer do not exceed primary drinkingwater standards (Anderson and Shaw, 1991). Waterquality constituents, which may be of concern where ground water is the source of drinking water include: sodium, chloride, and dissolved solids in areas affected by saltwater intrusion; hydrocarbons in urban-industrial areas; nitrate in localized areas of urban or suburban development; and organic carbon in areas where overlying peat deposits occur.

The surficial and intermediate aquifer systems, located to the west and north of the Biscayne aquifer, consist of interlayered beds of sand, peat, clayey sand, silt, and shell, with minor limestone beds. The surficial aquifer system can be further subdivided into: the medium-to-fine sand and clayey sand of the Lake Wales Ridge area (fig. 2); and the interbedded layers of sand, silt, and shell or limestone that are present in the central part of the study area (fig. 7). The surficial aquifer system in the Lake Wales Ridge area has a moderate recharge rate of approximately 25 to $38 \mathrm{~cm} / \mathrm{yr}$, and an aerobic saturated zone. The surficial aquifer system within the Lake Wales Ridge area is used primarily for domestic supply and small-scale agricultural irrigation supply. The sand, silt, and shell surficial aquifer system in the central and southern part of the study area generally has a water table close to the land surface, a low recharge rate of 2.5 to $23 \mathrm{~cm} / \mathrm{yr}$, and an anaerobic saturated zone.

The Biscayne aquifer and parts of the other surficial aquifer system are overlain by a layer of peat in the Everglades region (fig. 7). The peats of the Everglades are an accumulation of 0.3 to 3.3 m of peat, muck, and marl (Davis, 1943) which generally has a low permeability. The water table in the peats usually is less than $0.6 \mathrm{~m}$ below land surface in areas where the Everglades is not inundated.

The intermediate aquifer system is similar to the sand, silt, and shell surficial aquifer system but is somewhat deeper. The waters in the sand, silt, and shell surficial and intermediate aquifer systems are used extensively for public supply in all areas south of Lake Okeechobee and in cities along the western coastlines. Saltwater intrusion and free-flowing deeper artesian wells have rendered parts of these aquifer systems nonpotable. Concentrations of VOCs in ground water used for drinking-water supply are often of concern in urban areas on the east coast, and high radioactivity has been measured in ground water in the western part of the study area where saline water contacts phosphate deposits rich in natural radioactivity (Miller and Sutcliffe, 1985).

The Floridan aquifer system underlies the entire study unit and occurs near the land surface in the northern part but drops to $150 \mathrm{~m}$ below land surface in the southern part (McPherson, 1996). It consists of limestone and dolomite beds that are generally highly transmissive. The Floridan aquifer system generally contains older water or a mix of recent and older water. It is used extensively for public supply and agriculture in the northern part of the study area because goodquality water is relatively close to the surface and easily accessible. Conversely, in the southern part, the aquifer contains nonpotable water due to high salinity. Concentrations of most water-quality constituents in waters from the Floridan aquifer system generally do not exceed applicable drinking-water standards, although high concentrations of nitrate and pesticides may occur in ground water near current or former citrus grove operations.

\section{Issues of Regional Importance to Ground- Water Quality}

Ground water in southern Florida is vulnerable to many sources of contamination (Herr and Shaw, 1989). Issues of greatest concern are saltwater or brackishwater intrusion, nutrient enrichment, pesticides, metals and trace elements, volatile organic compounds, and radioactivity. Contaminants indirectly reach the ground-water systems in southern Florida from landfill leachates, spills of industrial organic solvents, and areal application of fertilizers and pesticides; and directly from leaking fuel storage tanks, septic systems, and drainage wells (Kimrey and Fayard, 1984; Irwin and Bonds, 1987; Bradner, 1991). Saltwater or brackish-water from remnant or recent seawater, and radioactivity from phosphatic deposits reach ground-water systems as a result of natural processes, but their occurrence may also be affected by human activities.

\section{Saltwater Intrusion}

Saltwater intrusion became a significant problem for urban water supply along the urban southeast coast in the 1940's and 1950's. Increased demand for freshwater resulted in increased pumping of the surficial 


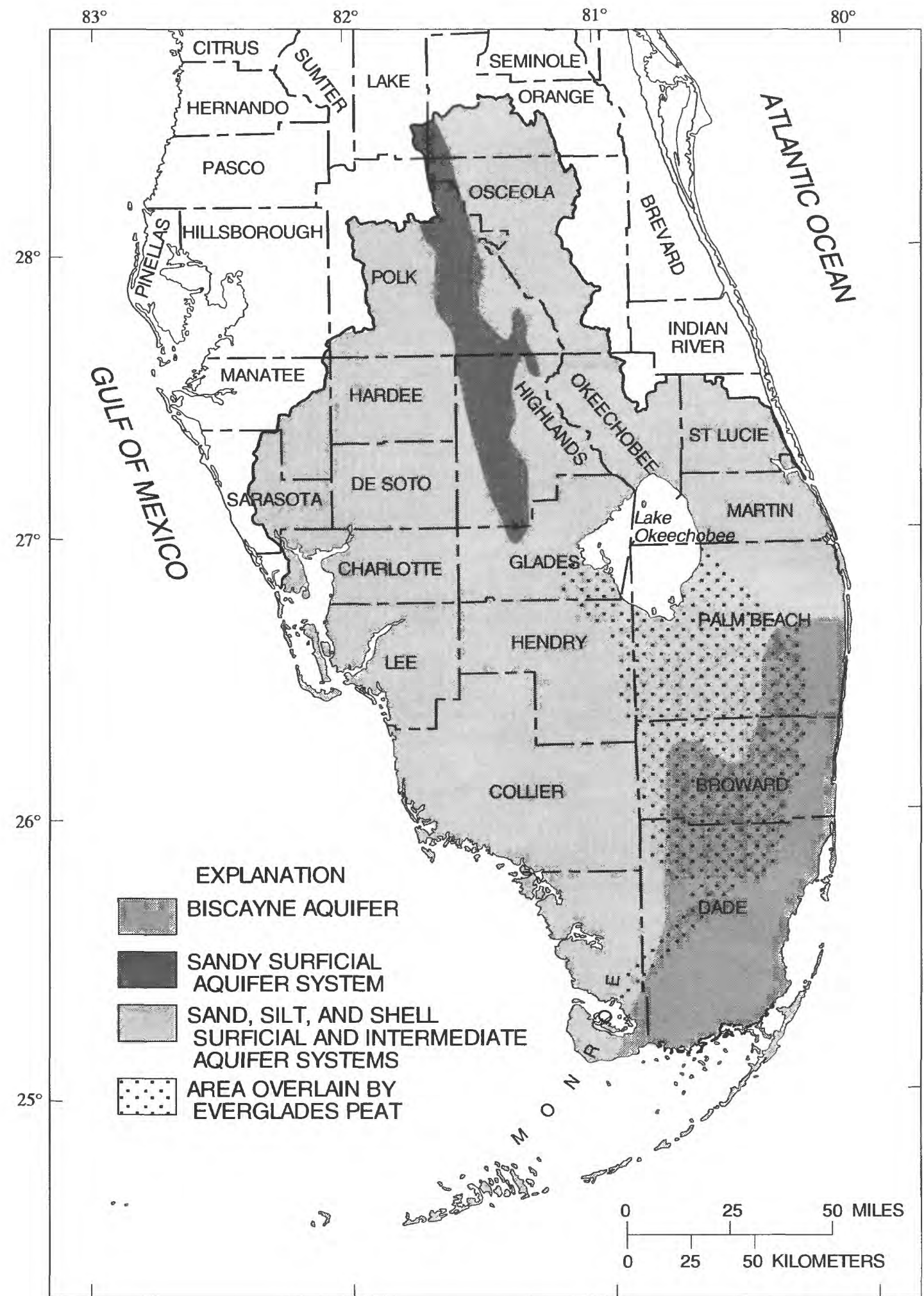

Base from U.S. Geological Survey digital data, 1:2,000,000, 1972

Albers Equal-Area Conic projection

Standard Parallels $29^{\circ} 30^{\prime}$ and $45^{\circ} 30^{\prime}$, central meridian $-83^{\circ} 00^{\prime}$

Figure 7. Aquifer systems in southern Florida and extent of peat in the Everglades region. 
aquifer system. At the same time, canals were dredged to drain land for development. These activities lowered water tables and allowed saltwater to move inland within the aquifer. The most severe problems have been somewhat alleviated through impoundment and storage of water in the WCAs which is later released to maintain sufficient water levels during dry seasons, and by restricting canal flow to the ocean during the dry season (Howie, 1987; Sonntag, 1987; Miller, 1988; Radell and Katz, 1991). Other strategies for improving the quality of the public-water supplies have included desalinization, rotation of well pumpage, and relocation of well fields to inland areas (Sonenshein and Hofstetter, 1990).

Saltwater intrusion also has occurred on the southwest coast of Florida in areas of urban development (Duerr and others, 1988; Duerr and Enos, 1991; Florida Geological Survey, 1992; Trommer, 1993). Saltwater intrusion into highly phosphatic zones of the intermediate aquifer can release large amounts of radium -226 into the ground water (Miller, 1992). Brackish water from deep, free-flowing, abandoned irrigation wells has infiltrated many localized areas in the central part of the study unit. Strategies for improving the quality of the surficial aquifer in these areas involve plugging abandoned wells and backplugging saltwater-flow zones in deep wells (LaRose, 1990; Bradner, 1994).

\section{Nutrient Enrichment}

Sources of nutrient enrichment of ground water in southern Florida include fertilizer application, stormwater runoff, and wastewater disposal. Nutrients in ground water are a concern in southern Florida because of their potential effect on human health and on surface waters. Nutrients such as nitrate and ammonia present in high concentrations in ground water may pose a threat to human health because most drinking water in southern Florida is from ground-water sources. Shallow ground water and surface water in southern Florida are closely connected and rapidly interchange. Therefore, nutrient-rich ground water that seeps or is pumped into surface-water bodies can contribute to nutrient enrichment and undesirable algal growth.

Fertilizer applied to citrus groves, vegetable crops, golf courses, and residential areas is a source of nitrate, ammonia, and phosphorus in ground water in southern Florida. For example, nitrate concentrations exceeding $30 \mathrm{mg} / \mathrm{L}$ have been detected in ground water beneath citrus growing areas in the Lake Wales Ridge area
(German, 1996) and in the upper part of the Biscayne aquifer in the vicinity of vegetable-growing areas (Florida Department of Environmental Protection, Public Water System, written commun., 1995). The highest number of wells yielding water exceeding the drinking-water standard for nitrate $(10 \mathrm{mg} / \mathrm{L})$ (Florida Department of State, 1993) are in Polk and Highlands Counties near the citrus-growing areas (822 domestic supply wells) and in Dade County near the vegetablegrowing areas ( 7 noncommunity supply wells) (Florida Department of Environmental Protection, Pesticide Contaminant Monitoring System, written commun., 1995). Generally, as recharge water with high organic nitrogen concentration enters anaerobic zones of the aquifer system, conversion to ammonia occurs by mineralization. High ammonia concentrations have been detected in ground water in the Biscayne aquifer near a golf course (Swancar, 1996). Although phosphorus is not typically a problem in ground water, runoff of phosphorus-rich ground water used for irrigation may result in algal blooms in wetlands, lakes, and streams.

Stormwater runoff may enter ground water through drainage wells or percolation ponds. Shallow drainage wells in Dade and Broward Counties that divert stormwater into the Biscayne aquifer may be a source of ammonia contamination (Kimrey and Fayard, 1984). Drainage wells in Orange County that divert stormwater by gravity flow into the Floridan aquifer system are also a source of ammonia contamination (Bradner, 1991).

Wastewater disposal is a widespread sources of nutrient contamination to ground water. For example, citrus processing wastes and wastewater treatment plant effluent are often applied to sprayfields or placed into percolation ponds (Bradner, 1991; Sumner and Bradner, 1996). Wastes from dairy operations contain high concentrations of phosphorus and nitrogen (Federico, 1977; Lake Okeechobee Technical Advisory Council, written commun., 1989; South Florida Water Management District, 1989) which may be transported in surface-water runoff and subsequently contaminate shallow ground water overlain by sandy soils. Nutrients from septic tanks and shallow disposal wells can potentially seep into surface water and contribute to enrichment and degradation of surface water and ground water. In the Florida Keys, there are more than 25,000 septic tanks, 5,000 cesspools, and 600 shallow drainage wells that release nutrient-rich water into very porous limestone. There is concern that nutrients from these sources may seep into shallow marine 
waters and adversely affect this environment, including the coral reefs. Recent studies have reported high concentrations of ammonia in shallow ground water offshore of the Keys (Shinn and others, 1994; Paul and others, 1995).

\section{Occurrence and Distribution of Pesticides}

Pesticide use in southern Florida includes ground and aerial application of pesticides for agriculture, mosquito control, and aquatic weed control; and pesticide use on golf courses, residential property, and power and transportation right-of-ways. Many pesticides reach shallow ground water by runoff and percolation through the soil; however, the transport and degradation of pesticides in ground water are not well understood. Pesticides detected in wells tapping the surficial aquifer system include the herbicides bromacil, diuron, and propazine; and the insecticides 1,2Dibromoethane (EDB), aldicarb, carbofuran, and endosulfan sulfate (Florida Department of Environmental Protection, Groundwater Monitoring Program, written commun., 1995).

A widespread source of ground-water contamination by pesticides in southern Florida is heavy application in citrus groves. Bromacil is widely applied to citrus groves and has been frequently detected in citrus-growing areas. Untreated water samples from more than 800 domestic-supply wells in Polk and Highlands Counties contained detectable concentrations of bromacil (Florida Department of Environmental Protection Groundwater Monitoring Program, written commun., 1995). By 1995, 56 of these wells had water samples with bromacil concentrations greater than the health-advisory concentration of $90 \mu \mathrm{g} / \mathrm{L}$ (Florida Department of Environmental Regulation, 1989; Florida Department of Health, Environmental Toxicology, written commun., 1995). Diuron is commonly combined with bromacil for application in citrus groves; however, detections of diuron are less frequent and generally at lower concentrations than bromacil (Florida Department of Environmental Protection, Groundwater Monitoring Program, written commun., 1995). The herbicide propazine, used for weed control in sorghum (a common feed crop for cattle), was detected in several background wells in Collier, Glades, Hendry, and Lee Counties. The extent of propazine contamination has not been determined because the counties cover large areas of land and the background wells are sparsely located.
One of the most publicized contaminants is EDB, which was banned for agricultural use in Florida in 1983 (Katz, 1993). By 1995, more than 1,000 domestic supply wells in the sandy ridge area of Polk and Highlands Counties were contaminated by EDB (Florida Department of Environmental Protection, Pesticide Contaminant Monitoring System, written commun., 1995). Many of the contaminated wells are located in areas where former citrus groves were converted to residential developments. In these developments, drinking water is supplied by individual shallow wells. Traces of EDB also are detected in ground water in other parts of the study area. Sources of EDB contamination in areas away from citrus groves have not been determined.The fumigant methyl bromide is now being used instead of EDB as an insecticide in southern Florida; further studies are needed to determine whether ground water has been contaminated in areas where methyl bromide is being used.

Aldicarb, a carbamate insecticide, has been detected in water samples from more than 100 wells that tap the surficial aquifer system in current and former citrus-growing areas in Orange, Polk, and Highlands Counties (German, 1996), as well as in water samples from background wells (Florida Department of Environmental Protection, Groundwater Monitoring Program, written commun., 1995). Carbofuran, another carbamate insecticide, was detected in water from one background monitoring well, but has not been detected in water from domestic supply wells in the areas where other insecticides have been detected (Florida Department of Environmental Protection, Ground Water Monitoring Program, written commun., 1995) Endosulfan I and II, insecticides that are used on vegetables and citrus, have been detected in surface waters in southern Florida (R.J. Miles and C.J. Pfeuffer, SFWMD, written commun., 1995). Only endosulfan sulfate, a less hazardous breakdown product of the two parent compounds, has been detected in ground water in the study area.

\section{Volatile Organic Compounds}

Detections of volatile organic compounds (VOCs) in ground water are common in urban areas and sporadic in rural areas in southern Florida. The principal VOCs detected in untreated ground water used for public supplies are the halogenated aliphatic hydrocarbons, particularly trichloroethene, vinyl chloride, and tetrachloroethene; and the monocyclic aromatics hydrocarbons such as benzene, toluene, and xylenes. 
A study of public-water supplies in Broward, Dade, and Palm Beach Counties reported that 27 large public water systems had detectable levels of VOCs in the raw water supplied to the utilities (Vincent, 1984). Numerous drinking-water utilities in southeastern Florida treat raw ground water contaminated by halogenated aliphatic hydrocarbons (fig. 8a) and monocyclic aliphatic hydrocarbons (fig. 8b). Concentrations of these compounds in raw untreated water samples sometimes exceed drinking-water guidance concentrations. Many of these water-supply systems are using air stripping techniques to remove significant quantities of vinyl chloride and trichloroethene from raw water as a part of the treatment process (FDEP Public Water Supply, written commun., 1995). Samples from background monitoring wells were also reviewed for detections of halogenated aliphatic hydrocarbons (fig. 8c) and monocyclic aromatics hydrocarbons (fig. 8d). The highest densities of background monitoring wells with detections of these VOCs in raw water samples were in Polk, Martin, Dade, and Palm Beach Counties.

\section{Metals and Trace Elements}

Natural iron sources are widespread in southern Florida's aquifer systems. Sources include oxidation of pyrite and organic compounds, and the dissolution of iron oxide and silicate minerals (Florida Geological Survey, 1992). Iron can be mobile in some ground water environments and can occur in relatively high concentrations ( $>1.0 \mathrm{mg} / \mathrm{L})$. Iron in ground water is an issue of concern primarily for esthetic reasons, and it can be easily removed using conventional treatment methods.

Trace elements are generally present at low $(<0.001 \mathrm{mg} / \mathrm{L})$ concentrations in ground water in southern Florida (Florida Geological Survey, 1992). Lead, arsenic, and mercury in ground water are of concern because of their potentially toxic effects on the biota. Lead concentrations in ground water samples from background monitoring wells sometimes exceed the $50 \mu \mathrm{g} / \mathrm{L}$ primary drinking water standard, but some of these detections may be artifacts of well contamination. Lead mobility should be limited by sorption on clays and organic compounds (Florida Geological Survey, 1992).

Arsenic has been a contaminant around old cattledipping pits in the vicinity of cattle ranches (Blasland, Bouck, and Lee, 1992), but these areas are very small compared to the large size of the ranch (usually thou- sands of hectares in drained prairie wetland compared to about 1 ha of contamination). Arsenic has been detected in the bed sediment of canals in southern Florida (Sherwood and others, 1973); further studies are needed to determine whether the ground water in these areas has been contaminated. Arsenic has also been detected in ground water beneath golf courses where the arsenic-containing compound MSMA has been applied for weed control (Swancar, 1996).

Mercury is generally in low concentrations in ground water in southern Florida, but an abundance of dissolved organic compounds in ground water is conducive to the transport of mercury. Surficial ground water in the Everglades may be enriched in certain constituents that enhance mercury cycling. Sulfate-reducing bacteria in peat soils of the Everglades may enhance the transformation of inorganic mercury to methyl mercury, a toxic form that concentrates in the biota. Studies are underway by the U.S. Geological Survey to evaluate biogeochemical processes in the Everglades peat that might control mercury cycling (Krabbenhoft and Rickert, 1995).

\section{Radioactivity}

Much of the northwestern part of the study unit is underlain by phosphatic deposits containing phosphate ore (pebbles) that typically contains 100 to $150 \mathrm{ppm}$ of uranium, mainly uranium-238 (Guimond and Windom, 1975). Uranium is not very soluble in the reducing environment typical of ground water. Consequently, many of the studies of radioactivity in Florida have been related to uranium-238 daughter radionuclides such as radium-226 in drinking-water sources (Kaufmann and Bliss, 1977; Miller and Sutcliffe, 1985) or in ground water near phosphate chemical plants and mines (Miller and Sutcliffe, 1984); radon-222 in water and dwellings (Nagda and others, 1987); and polonium-210 in water (Harada and others, 1989) because of the cancer risk associated with ingestion or inhalation of these radionuclides. Phosphate ore occurs in greatest concentration in the intermediate aquifer, but the ore also occurs in other parts of the surficial aquifer system in southwestern Florida. Radium-226 in ground water often exceeds drinking-water regulations (5.0 $\mathrm{pCi} / \mathrm{L}$ ) in coastal counties and its radioactivity usually increases with dissolved-solids concentration due to ion exchange reactions (Miller and Sutcliffe, 1985). The highest radium-226 activity that Miller and Sutcliffe (1985) measured was $110 \mathrm{pCi} / \mathrm{L}$ in a sample with 

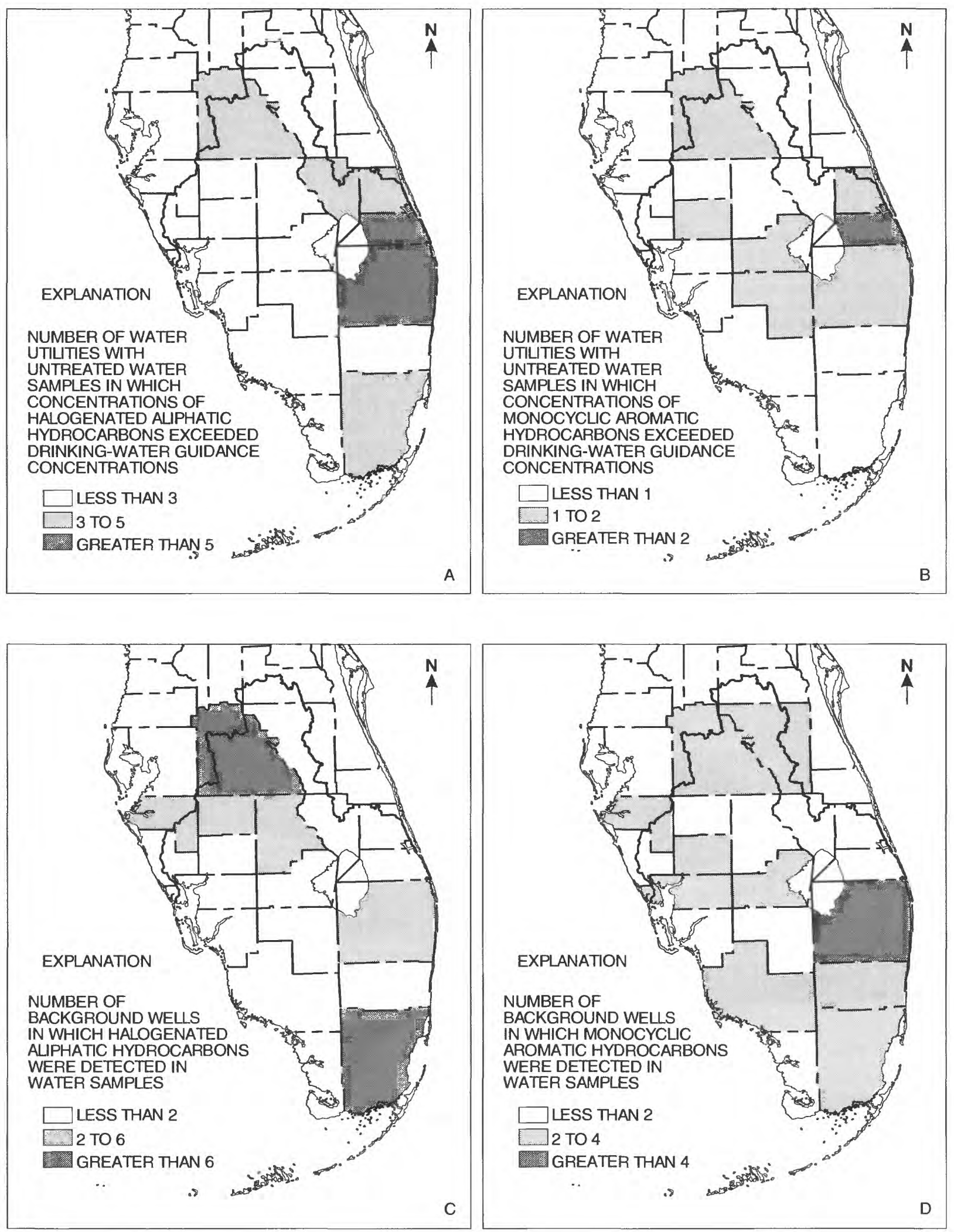

Figure 8. Occurrence of hydrogenated aliphatic and monocyclic aromatic hydrocarbons in ground water in southern Florida. 
a specific conductance of 19,000 microsiemens per centimeter at $25^{\circ} \mathrm{C}$. Efforts have been made to provide treated water from public water utilities to people living in areas with elevated radium-226 to reduce cancer risks associated with ingesting this bone-seeking radionuclide. Radon-222 concentrations in ground water in central Florida ranged from 20 to $46,000 \mathrm{pCi} / \mathrm{L}$ (Kaufmann and Bliss, 1977). Polonium-210 in ground water ranged from less than 0.05 to greater than $4.5 \mathrm{pCi} / \mathrm{L}$; tended to occur in shallow ground water with low $\mathrm{pH}$, high sulfide, and high radon-222; and may be released by bacterial action (Harada and others, 1989).

\section{AQUATIC ECOLOGY IN SOUTHERN FLORIDA}

The biological communities of aquatic ecosystems in southern Florida reflect past and present water-quality conditions and simultaneously influence the nature of future water quality through a series of complex and dynamic interactions.

\section{Overview of Aquatic Ecology}

Wetlands are the dominant aquatic systems in the surface-water basins of southern Florida (table 4). These wetlands include a variety of ecosystem types including cypress strands, cypress domes, flatwoods sloughs, hardwood swamps, prairies, marshes, and riv- erine/lacustrine flood plains (Livingston and Fernald, 1991). Freshwater wetlands merge with coastal wetlands and sustain them through seasonal sheetflow of waters with low nutrient concentrations. A large number of canals cut through the wetlands of southern Florida and are isolated from the ecosystems of the adjacent wetlands. These canals are often dredged to facilitate maximum discharge and have habitat characteristics very different from surrounding wetlands, natural rivers, and streams. Unchannelized rivers, such as the Myakka and the Peace Rivers, constitute a relatively small part of the surface water ecosystem in southern Florida.

The Big Cypress Basin, including the Big Cypress Swamp and the BCNP, is a unique wetland environment in southern Florida. The Big Cypress Basin differs from the adjacent Everglades in that it has relatively higher land elevation, thinner soils of marl or sand, and widespread forest vegetation (McPherson, 1974). Natural drainage in the Big Cypress is by slow, overland flow of water to the south, and well-defined streams generally do not exist (McPherson, 1984).

Freshwater vegetation in the Big Cypress Basin primarily consists of cypress forests, mixed swamp forests, willow thickets, prairies, marshes, and ponds (Duever, 1984); cypress and hardwood vegetation is dominant (table 4). Periphyton is also an important component of wet prairies, coastal marsh, and dwarf cypress communities. Blue-green algae precipitate

Table 4. Extent of wetlands in drainage basins in southern Florida

\begin{tabular}{|c|c|c|c|c|c|c|c|c|}
\hline \multirow[b]{2}{*}{ Basin } & \multirow{2}{*}{$\begin{array}{c}\text { Total basin } \\
\text { area, in } \\
\text { hectares }\end{array}$} & \multicolumn{7}{|c|}{ Hectares of wetlands ${ }^{1}$} \\
\hline & & Cypress & Hardwoods & $\begin{array}{l}\text { Marsh } \\
\text { and } \\
\text { slough }\end{array}$ & Lakes & $\begin{array}{c}\text { Canals } \\
\text { and } \\
\text { rivers }\end{array}$ & Mangrove & $\begin{array}{c}\text { Salt } \\
\text { marsh }\end{array}$ \\
\hline Big Cypress & 649,000 & 184,000 & 75,300 & 51,500 & 1,360 & 358 & 58,200 & 9,260 \\
\hline Caloosahatchee River & 349,000 & 7,240 & 5,960 & 18,200 & 377 & 1,070 & 1,090 & 200 \\
\hline Everglades Agricultural Area & 270,000 & 0 & 49,900 & 351 & 49 & 769 & 0 & 0 \\
\hline Everglades & 935,000 & 55,900 & 96,500 & 111,000 & 61 & 1,930 & 125,000 & 24,000 \\
\hline Florida Keys & 39,400 & 0 & 0 & 0 & 0 & 0 & 12,300 & 59 \\
\hline Kissimmee River & $1,060,000$ & 13,600 & 37,600 & 96,800 & 79,600 & 3,510 & 0 & 0 \\
\hline St. Lucie River & 351,000 & 5,890 & 5,270 & 50,300 & 491 & 2,360 & 1,060 & 91 \\
\hline Lake Okeechobee & 181,000 & 15 & 4,620 & 10,200 & 88,600 & 878 & 0 & 0 \\
\hline Peace and Myakka Rivers & 840,000 & 4,790 & 55,600 & 40,300 & 21,200 & 1,360 & 13,700 & 2,320 \\
\hline East Coast Urban Area & 412,000 & 126 & 12,100 & 48,300 & 5,940 & 2,350 & 7,090 & 1,390 \\
\hline
\end{tabular}


considerable amounts of calcium carbonate, which forms calcitic mud or marl found throughout the Big Cypress (Duever and others, 1986).

Little is known about the ecology of the invertebrates in the Big Cypress Basin (Drew and Schomer, 1984). Among the most abundant fish in the Big Cypress Basin are the Florida gar, the bowfin, the lake chubsucker, the swamp darter, species of killifish, and the mosquito fish (Drew and Schomer, 1984; Duever and others, 1986). The Big Cypress Basin is perhaps the most ecologically undisturbed natural wetlands system in southern Florida (Duever, 1984). Major contemporary perturbations to the ecology of the Big Cypress include agriculture and residential development on the periphery of the basin, oil exploration, offroad vehicle use, construction of roads and an airport, and limerock quarrying.

The Kissimmee River, Lake Okeechobee, and the Everglades watersheds are a complex, highly modified system where watershed boundaries and ecological relations are difficult to assess. The Kissimmee River is in a state of transition as a result of efforts to restore the hydrology of the Kissimmee-Okeechobee-Everglades system to an approximation of predevelopment conditions.

Historically, the Kissimmee River meandered for about $160 \mathrm{~km}$ through its watershed and periodically overflowed its banks to inundate an adjacent wetland mosaic of broadleaf marsh, wet prairie, and wetland shrub communities (Milleson and others, 1980), which made up 20 percent of the watershed (Kushlan, 1991). By the early 1980's the Kissimmee River had been transformed into a canal (sometimes called C-38) about 90-km long, fitted with a number of water-control structures.

Wetlands are much reduced in extent, and the wetlands that remain are homogeneous plant communities confined to the lower, impounded parts of each pool (Toth, 1993). At least 39 species of native freshwater fishes were present in the pre-impounded Kissimmee River Basin (Bass, 1991). Following canalization, only 17 fish species were collected, and the proportion of game species decreased from 43 to 28 percent (Davis and others, 1990). Macroinvertebrate communities in the canalized reaches are generally characterized by low invertebrate density and low species richness (Rutter and others, 1986; Toth, 1993). Restoration of the Kissimmee River, including a 4-year demonstration project designed to recreate hydrologic conditions prevalent during predevelopment times, has provided a focus for recent ecological studies (Toth, 1993).
Lake Okeechobee is a shallow, naturally eutrophic lake which is extensively influenced by nutrient enrichment from human activities. Primary production is limited by nutrient concentration and/or light. In some years algal blooms of blue-green species (cyanobacteria) cover more than 40 percent of the lake surface in late June and early July (Brezonik and others, 1987). Average annual chlorophyll $a$ concentrations (a common measure of productivity of algal populations) ranged from 19 to $27 \mu \mathrm{g} / \mathrm{L}$ during 1974-84 (Canfield and Hoyer, 1988). The highest chlorophyll $a$ concentrations were measured in the northern and western parts of the lake (Phlips and others, 1994). The relative importance of factors contributing to frequency and intensity of algal blooms has not been determined. Phosphorus inputs, disturbance and resuspension of nutrient-rich bed sediments, and other factors are all being studied to quantify their relative contributions to blooms of blue-green algae. The lake contains large nuisance populations of several exotic aquatic macrophytes, including water hyacinth, hydrilla, and water lettuce. Periodic application of herbicides for control of nuisance macrophytes results in greater light penetration and greater availability of plant nutrients, which in turn promotes subsequent algal blooms.

The Everglades is a large, peat-based wetland that historically covered about $11,000 \mathrm{~km}^{2}$. In modern times, the Everglades watershed south of Lake Okeechobee has been drained and divided into the EAA, the WCAs, and the ENP. The EAA is an area of drained wetlands used for large-scale agricultural production of sugar cane, winter vegetables, and rice. The WCAs are diked, vegetated, shallow-water reservoirs designed for flood control and water supply. The ENP contains about 20 percent of the original Everglades system now preserved for wilderness and wildlife habitat.

The majority of the wetlands already lost from the Everglades system may never be restored because restoration would come at an incalculable cost to agriculture and the millions of residents living on the already drained land. Maintaining the remaining wetlands in the Everglades system as a self-sustaining multi-use resource which provides water supply, flood control, and water-quality enhancement is the goal of present (1995) interagency efforts.

The Everglades has been described as the most intensely studied wetlands in the world (Kushlan, 1991). Historically, the Everglades was dominated by sawgrass, Cladium jamaicense. This dominance is presumably due to the tolerance of sawgrass for very low nutrient concentrations (Steward and Ornes, 1975). 
Sawgrass does not have a competitive advantage over other macrophytes, such as cattail, under high-nutrient conditions.

Periphyton is an important component of the ecosystem in many areas of the Everglades; periphyton varies in composition according to nutrient concentration and hydropattern (defined as the depth of water, and the duration and timing of freshwater inundation). Desmids, filamentous green algae, and certain species of diatoms are present in acid, low-mineral, low-nutrient habitats such as those present in the interior of WCA-1. Rainfall is the primary source of water-quality constituents in these habitats. In marsh areas with low nutrient concentrations but high dissolved-mineral content, calcareous blue-green algae and diatoms dominate the periphyton community. These areas occur in interior parts of WCA-2 and WCA-3, and in parts of the ENP. Marsh areas adjacent to and fed by the EAA canals carrying drainage water with high nutrient and dissolved-mineral concentrations typically contain periphyton dominated by filamentous, nutrient-tolerant, blue-green algae and diatoms (Swift, 1984; Swift and Nicholas, 1987). Calcareous periphyton and the formation of an algal mat are characteristic of Taylor Slough and other areas where the hydroperiod (the duration of freshwater inundation) is 6 to 7 months. At sites with a longer hydroperiod, approaching year-round flooding, periphyton composed of green algae, especially desmids, is common (Browder and others, 1981).

A review of data on periphyton food utilization by macroinvertebrates and vertebrate animals in the Everglades indicates that diatoms are a preferred food source; green algae are consumed less frequently, and blue-green algae are likely an unsuitable food for many invertebrates, fish, and other organisms (Browder and others, 1994).

Fish are an important component of the Everglades ecosystem, and they function at many levels of the food web ranging from primary consumers of vegetation and detritus, to secondary consumers of invertebrates, and finally as top predators (Loftus and Eklund, 1994). Forty-three species of fishes in 18 families, including at least four exotic species, were collected in the Everglades during 1962-74 (Dineen, 1974). Only two longterm, quantitative studies of Everglades freshwater fishes have been conducted, and both occurred within the ENP (Loftus and Eklund, 1994). It is likely that the intensity of human activities in southern Florida will result in ecosystem alterations that will influence the fish community composition.
The Myakka River, Peace River, Caloosahatchee River, and other streams are locally important components of surface-water systems in the northwestern part of the study unit. The Myakka River is one of southern Florida's most pristine rivers (Estevez and others, 1991), and the lower two-thirds of the river is designated as an Outstanding Florida Water (Livingston, 1991). The basin still contains areas of forested wetlands and large amounts of instream and bankside logs, branches, roots and other snag habitats. Submersed aquatic vegetation is relatively scarce (Canfield and Hoyer, 1988), perhaps due to shading, and food chains are based on detrital inputs (Estevez and others, 1991). One exception is the natural in-stream lakes which are typically wide, grassy, and shallow lentic reaches in the main riverbed. In these habitats, insects are the most abundant invertebrates in the upstream reaches, whereas crustaceans dominate in the downstream parts of the river (Estevez and others, 1991).

In contrast to the Myakka River, the Peace River Basin contains a relatively small amount of undisturbed and public land, and the few remaining natural areas in the basin are being diminished by expanding citrus operations and phosphate mining. Blue-green algae with the capacity to fix nitrogen dominate the phytoplankton community in the phosphate-enriched streams of the Peace River Basin (Fraser, 1991). The Peace River contained 34 species of native freshwater fishes and a number of exotic species during 1983-88. The most abundant species collected were the Florida gar, bluegill, largemouth bass, and redear sunfish (Bass, 1991).

In the Caloosahatchee River, very low streamflow velocity and the presence of numerous oxbow lakes along the main channel allows the establishment of floating aquatic macrophyte communities including alligator weed, floating maidencane, water lettuce, and primrose willow. In the main channel of the river, emergent and floating vegetation is rare, and algae dominate the plant community (Drew and Schomer, 1984). Chlorophyll $a$ concentrations in the Caloosahatchee River vary seasonally, and maximum chlorophyll $a$ concentrations coincide with algal blooms of blue-green algal species including Anabaena flosaquae and Microsystis aeruginosa. Algal blooms occur downstream of wastewater treatment plants, and also downstream from sources of agricultural runoff including flower nurseries and citrus groves. At least 31 species of native freshwater fishes have been collected in the Caloosahatchee River (Bass, 1991). 


\section{Issues of Regional Importance to Aquatic Ecology}

The intensity and pervasive nature of human activities in southern Florida has significant consequences for the ecology of the aquatic habitats in the region. Although there are many issues of importance relating to aquatic ecology in southern Florida, those which are of particular interest include altered hydropatterns, the influence of nutrient enrichment, the occurrence and distribution of mercury, endocrine disruption and other effects of pesticides and other organic compounds, and the spread of exotic plant and animal species. The many factors relating to aquatic ecology in southern Florida are discussed separately in this report, for ease of presentation. However, in many cases these factors interact in complex ways, with consequences of greater magnitude for the biota than would otherwise be expected.

\section{Altered Hydropatterns}

Hydropatterns have been significantly altered in southern Florida from historical times. The hydroperiod in the Everglades marshes was 5 to 10 months, but under present conditions, many Everglades marshes are wet only 2 to 5 months per year. The dense sawgrass once covering the northern Everglades likely slowed the southward flow of water from rainfall and Lake Okeechobee overflow, resulting in a prolonged or continuous hydroperiod for the marshes farther south (Fennema and others, 1994). The conversion of the sawgrass marsh in the northern Everglades to agricultural fields and drainage canals may have had an indirect effect on hydropattern in the sawgrass marshes to the south in the WCAs, accelerating the rate of water flow and changing the timing of water supply (Walters and others, 1992). One goal of the Everglades Construction Project is to use treated water from the proposed STAs to improve seasonal water supply in the Everglades and specifically to reestablish sheetflow to the WCAs.

Changes in hydropattern have many ramifications for aquatic ecosystem structure (numbers and types of organisms) and function (processing and cycling of food and energy). Altered hydropatterns have influenced historic fire patterns in the BCNP (Duever and others, 1986). There appears to be a general increase in fires in the BCNP since 1971, although inconsistent records prior to 1970 preclude statistical analysis of these changes (Duever and others, 1986). Changes in dominant flora, for example a shift from sawgrass to cattail, may result from changes in hydrologic and fire regimes (Urban and others, 1993; Davis and others, 1994). Studies indicate that marshes with a longer hydroperiod have greater densities of macroinvertebrates than marshes with a shorter hydroperiod (Loftus and others, 1990). Densities of many small fish species that provide a food source for wading birds have been positively correlated with the number of months of marsh inundation (Loftus and Eklund, 1994). Two long-term, quantitative studies of Everglades fishes focus on the response of fish communities to changing hydroperiod (Kushlan, 1976; Loftus and Kushlan, 1987) and indicate that populations of larger predatory fish are enhanced during periods when the hydroperiod is extended.

Data from studies in the Kissimmee River Basin indicate that wetland communities can revert to predevelopment types within a year once the hydrologic regime is restored (Toth and others, 1993). Data also indicate that maintenance of diverse and self-sustaining littoral and flood-plain vegetation requires maintenance of continuous flow and widely varying stage and discharge regimes (Toth and others, 1993). Macroinvertebrate communities sampled adjacent to the Kissimmee River main channel following flow restoration indicate increased species richness especially of current-loving species (Rutter and others, 1989). However, unless water levels are deep enough for long enough, fish species cannot utilize marsh habitat to any extent in the Kissimmee watershed, and enhancement of game fish populations will not occur (Toth, 1993).

\section{Influence of Nutrient Enrichment on Habitat Integrity}

Historically, nutrient concentrations were low in the Everglades and controlled by nutrient concentrations in rainfall (Waller, 1982). In recent times, numerous areas of southern Florida have been subjected to nutrient enrichment. The EAA is the source of 45 percent of the phosphorus load discharged to the Everglades (South Florida Water Management District, 1995). During 1978-87 WCA-2 received at least 1,825 $\mathrm{Mg}$ of nitrogen and $61 \mathrm{Mg}$ of phosphorus per year from adjacent canals (South Florida Water Management District, 1992b). During 1978-91, an estimated mean annual load of $204 \mathrm{Mg}$ of total phosphorus was transported by EAA drainage/runoff water with 85 percent going to the south (South Florida Water Management 
District, 1992b). A north-to-south gradient of decreasing nitrogen and phosphorus concentrations has been documented across the WCAs (Belanger and others, 1989). Nutrient concentrations of up to 30 times the background concentration have been measured in canal water adjacent to the ENP (Gordon and others, 1986); however, the annual phosphorus input to the ENP has increased very little over predrainage inputs (Davis, 1994). Data indicate that phosphorus is more important than nitrogen as a limiting nutrient for plant growth in the Everglades system as a whole (Davis, 1994).

Studies show that algae and macrophytes respond rapidly (within days or weeks) to increased nutrient availability (Belanger and others, 1989; Grimshaw and others, 1993). Experimental additions of phosphorus at field sites in WCA-2 resulted in increased phosphorus uptake and increased biomass production by sawgrass communities (Craft and others, 1995). No significant change in macrophyte species diversity or expansion of cattail stands was observed in experimental plots receiving nutrient additions, but the duration of the study ( 2 years) may have been too short to show effects.

Numerous other studies indicate that nutrient enrichment in the Everglades has resulted in or contributed to the replacement of sawgrass and slough communities by cattail and disappearance of the native blue-green algae/ diatom-dominated periphyton mats (Flora and others, 1988; Belanger and others, 1989; Scheidt and others, 1989; Davis, 1991; South Florida Water Management District, 1992b). Increases in nutrient concentrations, however, do not fully explain the distribution of cattail in the Everglades. Urban and others (1993) monitored sawgrass and cattail densities in WCA-2 and reported that deep water, fire, and nutrient enrichment synergistically stimulated cattail expansion into sawgrass communities. Physical disturbance of any kind appears to provide cattail with a competitive advantage over sawgrass because cattail is adapted to function as an early colonizer in these habitats (Davis, 1994).

In the Everglades ecosystem, the dominant macrophyte type (sawgrass or cattail) can exert a profound influence on the ecology of the habitat (Belanger and others, 1989). Cattails have a shorter life cycle than sawgrass, so the production of detrital material (and associated biological oxygen demand) is greater. The shape and size of cattail leaves reduces reaeration and light availability at the water surface, thus reducing benthic algal photosynthesis and lowering dissolved- oxygen concentrations. Changes in organic bedsediment texture, dissolved-oxygen concentration, transpiration rate, and the community composition of microbial, periphyton, and macroinvertebrate populations occur following nutrient enrichment (Davis, 1994). Richardson (1994) and Craft and others (1995) reported a significant decline of the Utricularia-periphyton mat after only 1 year of nutrient additions and subsequent expansion of Chara (musk-grass) populations to replace the floating periphyton mat. Several studies have reported that macroinvertebrate diversity in the Everglades is naturally low (Waller, 1976; Loftus and others, 1990). Following a shift from sawgrass to cattail stands, a reduction in numbers of Diptera, snails, and isopods was observed, whereas the density of annelid worms doubled (Davis, 1994). Rader and Richardson (1992) reported no reduction in diversity, although their analyses of macroinvertebrate data were preliminary. Implications of a shift in macroinvertebrate community composition for the Everglades food chain are poorly understood but may be significant (Davis, 1994) and warrant further investigation.

The goal of the Everglades Construction Project is to reduce the phosphorus loading to the Everglades Protection Area by creating six STAs comprising about 16,000 ha of wetlands. In combination with implementation of on-farm Best Management Practices in the EAA, the STAs should keep phosphorus inflows to the Everglades Protection Area from exceeding $50 \mathrm{ppb}$ (South Florida Water Management District, 1994b). The Everglades Nutrient Removal Project is a prototype STA and operation was initiated in 1994 (South Florida Water Management district, 1994b). Data collected from this 1,600-ha constructed wetland will be used to refine and improve design, operation, and management of the Everglades Construction Project.

\section{Occurrence and Distribution of Mercury}

The build up of mercury in the environment is widespread in many parts of the world (National Academy of Sciences, 1978). Concentrations of mercury have increased worldwide in the atmosphere over the last 100 years, presumably as a result of industrialization. In Florida and particularly in the Everglades, the build up of mercury in bed sediment and biota has been pronounced (Atkeson, 1994). Analysis of bedsediment cores in the Everglades indicates that mercury accumulation rates are presently about six times higher than in 1900 (Delfino and Crisman, 1993). 
Most mercury entering the aquatic habitat from the atmosphere is primarily in the inorganic form. Mercury is then transformed by bacteria to the more toxic organic form (methyl mercury) in many aquatic systems. Most mercury detected in freshwater fish is methyl mercury (Grieb and others, 1990), which bioaccumulates through uptake from water or diet.

In 1989, high concentrations of mercury were detected in freshwater fish that were collected in a joint monitoring project by the FGFWFC, the Florida Health and Rehabilitative Services Department of Environmental Health, and the FDEP (Ware and others, 1990). Concentrations of mercury greater than $0.5 \mu \mathrm{g} / \mathrm{kg}$ were detected in largemouth bass collected from remote and urban lakes and rivers throughout Florida (Ware and others, 1990). Since that time, health advisories have been issued for more than 810,000 ha of aquatic habitat in southern Florida, including the BCNP, WCA-2, WCA-3, and the Shark River drainage in the ENP. During 199091, mercury concentrations were determined in largemouth bass from 53 sites in Florida. Mercury concentrations increased with fish age and size at all study sites, and exceeded the Florida health advisory standard $(0.5 \mu \mathrm{g} / \mathrm{kg})$ in fish from 24 of the 53 lakes sampled. Maximum concentrations of mercury detected in largemouth bass $(4.4 \mathrm{mg} / \mathrm{kg})$ and bowfin $(7 \mathrm{mg} / \mathrm{kg})$ from the Everglades are the highest concentrations detected in Florida (Stober and others, 1994).

A 1993 study of mercury in southern Florida indicated the presence of a north-to-south (high to low) gradient for total mercury and methyl mercury in water. Gradients were reversed (low to high) for total mercury in bed sediment and mosquito fish tissue (Stober and others, 1995). Bed sediment from Military Canal had the highest concentrations of mercury of any site in Dade County (SFWMD, 1994), and mobilization from the bed sediment into the food chain may occur. Mercury accumulation through the food web may suppress the breeding success of wading birds (Frederick and Spalding, 1994) and contribute to the endangered status of the Florida panther (Roelke and others, 1991).

Sources of mercury in southern Florida ecosystems are not well understood. Atmospheric transport and deposition from global and regional sources is one likely source. Periodic inundation of natural mineral and peat deposits during fluctuating water levels may facilitate mercury mobilization (Delfino and Crisman, 1993; Lange and others, 1993). Other waterborne sources may include release from limestone formations underlying the Everglades, and runoff from periodi- cally burned croplands in the EAA. Definitive studies of the influence of water quality on mercury transformation and uptake are not complete, and at this time (1996) correlations between other water-quality constituents and mercury concentrations in biota have not been substantiated. Numerous studies of mercury occurrence and distribution in water, bed sediment, and biota, as well as process-oriented studies of mercury mobilization, transformation, and bioaccumulation, are underway in southern Florida (Mercury Technical Committee, 1991).

\section{Endocrine Disruption and Other Effects of Pesticides on Biota}

Pesticides and other organic compounds are detected throughout the ecosystems of the world (Simonich and Hites, 1995). The same suite of characteristics which make pesticides effective (persistence, low volatility, low water solubility, high lipid solubility, and low rate of biodegradation) also may lead to bioaccumulation and biomagnification with resultant toxicity in nontarget wildlife and humans (Bason and Colborn, 1992). Pesticide use is so widespread in southern Florida that documenting the extent of use is difficult (Scheidt, 1989). As of the late 1980's, at least 88 pesticide compounds were used in southern Florida agriculture (Scheidt, 1989). Principal regional pesticide uses include ground and aerial spraying of pesticides for agriculture, mosquito control, and aquatic weed control, and application of pesticides on golf courses, on residential property, and on power and transportation right-of-ways.

The only long-term pesticide monitoring program in southern Florida is carried out by the SFWMD; longterm quarterly monitoring sites for a suite of 68 pesticides in surface water and hydrosoil are confined to the canal system and no marsh sites are included (Scheidt, 1989). No ongoing programs to monitor pesticides in wildlife existed as of the late 1980's (Scheidt, 1989).

Fish were collected in the WCAs during 1971-72 and in the ENP during 1969-70 for pesticide analyses. Measurable concentrations of DDT $(6-218 \mu \mathrm{g} / \mathrm{kg})$, dieldrin $(6-130 \mu \mathrm{g} / \mathrm{kg})$, toxaphene $(2,200-5,000$ $\mu \mathrm{g} / \mathrm{kg}$ ), and PCBs (10-100 $\mu \mathrm{g} / \mathrm{kg}$ ) were detected in tissue from largemouth bass, bluegill, and several sunfish species (McPherson, 1973). No detectable concentrations of aldrin, endrin, heptachlor, lindane, or chlordane were measured in that study. Measurable concentrations of several pesticides including 
chlordane, oxychlordane, p,p DDE, and nonachlor were detected in fish fillet tissue samples collected in Collier County in 1995 (Al Ruth, Collier County Environmental Services Division, written commun., 1995). Measurable concentrations of endrin were detected in fish tissue samples collected in a remote area of Fakahatchee Strand State Preserve, and dieldrin was detected in fish tissue samples collected in Lake Trafford. The focus of recent monitoring efforts couples analyses of water and bed sediment with analyses of biota at various levels in the food chain (filterers, gatherers, predators) to obtain information on bioaccumulation and biomagnification of pesticides and other organic compounds.

A large number of pesticides and other organic compounds with widespread distribution in the environment are reported to have endocrine-disrupting effects (Colborn and others, 1993). Reproductive anomalies have been observed in fish, wading birds, the American alligator, and other animals living in ecosystems polluted by compounds that disrupt the endocrine system (Davis and Bradlow, 1995). The National Biological Service has collected fish from several sites in southern Florida as well as from numerous sites throughout the United States; analyses to determine estrogen/testosterone ratios were in progress in 1996 (Wade Bryant, National Biological Service, written commun., 1995). Coupled with analyses of fish tissue for the presence of pesticides and other organic compounds, these data may indicate areas in southern Florida where organisms are at greatest risk from pesticide contamination.

\section{Spread of Exotic Plant and Animal Species}

Exotic aquatic and wetlands plants are spreading rapidly through many parts of southern Florida. Invading plant species of greatest concern include melaleuca (Melaleuca quinquinervia), Australian pine (Casuarina equisetifolia), Brazilian pepper (Schinus terebinthifolius), hydrilla (Hydrilla verticillata), and water hyacinth (Eichornia crassipes) (Exotic Pest Plant Council, 1993). Melaleuca has invaded more than 200,000 ha in Florida. Infestations occur in Lake Okeechobee's marshes, the WCAs, the BCNP, and areas east of the ENP. The BCNP is vulnerable to invasion of aggressive exotic plant species, particularly in areas disturbed by off-road vehicles, fire-control activities, construction, and drainage projects. The northwestern quadrant of the BCNP is most vulnerable to establishment of melaleuca forest because of the area's deep sandy soils, which are preferred by melaleuca (Duever and others, 1986). Agricultural activities associated with conventional crop farming, including alteration of patterns of periodic floods and fires, have also facilitated the invasion of a number of exotic species especially in the northern part of the area (Duever, 1984).

By the early 1990s, 15 to 17 species of exotic fishes were considered to be well established in southern Florida, and at least 7 of these species were present in the Everglades (Robertson and Frederick, 1994).The detrimental effects of exotic fish species include predation on native fish species and competition with native fish species for habitat and food. These activities can result in negative impacts on animals at other levels of the food chain. However, some exotic fish species are highly productive in marsh habitats and may produce a significant amount of food for predatory bird species

(Robertson and Frederick, 1994), thereby making these exotic fish species valuable to the food web in southern Florida. The National Biological Service is presently collecting data on distribution, abundance, and food habits of exotic fish species in southern Florida to assess their role and effect on the ecosystem.

\section{SUMMARY}

Historically, southern Florida surface waters were characterized by large areas of wetlands that were drained by numerous small coastal streams and several large rivers. Today, surface water exists in southern Florida in a complex system of highly modified and intensively managed wetlands, lakes, canals, and regulated rivers. Surface-water basins are not well-defined and discharge in some rivers and canals may cease or be reversed at times of the year when backpumping is used to manage local water levels and regional water supply. The quality of surface water has been and continues to be profoundly influenced by altered patterns of water flow, atmospheric deposition of nutrients and other contaminants, runoff from agriculture and livestock operations, phosphate mining, urban runoff, municipal wastewater discharge, and other human activities.

Development of a nutrient budget for southern Florida is a goal of several agencies involved in ecosystem restoration in the region. The relative contributions of various point and nonpoint sources of phosphorus 
and nitrogen were estimated in nine surface-water basins in the Southern Florida NAWQA study unit. Fertilizer and manure from agriculture account for much of the nutrient inputs. Fertilizer is the dominant source of phosphorus in eight basins and the dominant source of nitrogen in at least five basins. Canal inflow is the largest source of phosphorus input to Lake Okeechobee and the second largest source of nitrogen input to the lake. Atmospheric sources of nitrogen contribute more than 20 percent of the total nitrogen input to all basins and are the dominant source of nitrogen input to Lake Okeechobee and the Everglades.

Nutrient loads in selected canal and river outflows in southern Florida were estimated using data collected by the SFWMD and the USGS. Annual phosphorus loads from the Peace River are the highest in the study unit; annual phosphorus loads from the Caloosahatchee River and the major Palm Beach canals are also high, compared to other parts of southern Florida. Estimated annual loads of phosphorus from parts of the Big Cypress Basin and the S-12 water-control structures of the Tamiami Canal are low compared with estimated phosphorus loads in outflows in the northern part of the study unit. Annual nitrogen loads in southern Florida were highest in outflows from the Caloosahatchee River Basin and the major Palm Beach canals. Nitrogen loads in outflows from parts of the Big Cypress subbasin were lower than those estimated to the north.

The principal aquifers in southern Florida are the Biscayne aquifer, the surficial and intermediate aquifer systems, and the Floridan aquifer system. Waters in all the aquifer systems are primarily a calcium bicarbonate type, mostly because shell, limestone, or dolomite is abundant in the aquifers. The waters are generally hard to very hard. Ground water is the most important drinking-water resource in southern Florida; about 5.5 million people depend on ground water as a primary source of drinking water.

Ground water in southern Florida is vulnerable to contamination because of its close proximity to the surface. Ground-water contamination issues of greatest concern include: saltwater or brackish-water intrusion, nutrient enrichment, pesticides, metals and trace elements, volatile organic compounds, and radioactivity. Most contaminants reach the ground-water system in southern Florida indirectly through the land surface from landfill leachate, spills of industrial organic solvents, and areal application of fertilizers and pesticides; and directly from leaking fuel storage tanks, septic systems, and drainage wells. Saltwater or brackish water from remnant or recent seawater, and radioactivity from phosphatic deposits reach ground-water systems as a result of natural processes, but their occurrence may also be affected by human activities.

Wetlands are the dominant aquatic ecosystem type in the surface-water basins of southern Florida, and include the cypress forests of the Big Cypress Basin, the sawgrass marshes of the Everglades, and the mangrove forests of coastal waters. Freshwater wetlands merge with coastal wetlands and sustain them through seasonal sheetflow of waters with low nutrient concentrations. A large number of canals cut through the wetlands of southern Florida and are isolated from the ecosystems of the adjacent wetlands. These canals are often enriched with nutrients, are periodically dredged to facilitate maximum discharge, and have habitat characteristics very different from surrounding wetlands, natural rivers, and streams. The biological communities of aquatic ecosystems in southern Florida reflect past and present water-quality conditions and simultaneously influence the nature of future water quality through a series of complex and dynamic interactions.

The intensity and pervasive nature of human activities in southern Florida has had significant consequences for the ecology of the aquatic habitats in the region. Although there are many issues of importance to aquatic ecology in southern Florida, those which are critical to the ecosystem include: altered hydropatterns; the influence of nutrient enrichment; the occurrence and distribution of mercury; endocrine disruption and other effects of pesticides and other organic compounds; and the spread of exotic plant and animal species. The many factors influencing aquatic ecology in southern Florida interact in complex ways, with consequences of greater magnitude for the biota than those expected if the individual factors acted separately.

Surface-water quality, ground-water quality, and aquatic ecology in southern Florida are being studied (1996) in the context of ecosystem restoration by numerous Federal, State, and local agencies, and by private organizations. There is a widespread commitment to develop a fundamental understanding of ecosystem function in southern Florida. Efforts are underway to formulate and implement a broadly based, basin-wide water management strategy for the region in order to restore and maintain a sustainable ecosystem in southern Florida. The U.S. Geological Survey is a participant in these efforts, and the data collected in the Southern Florida NAWQA study unit will contribute to ecosystem restoration efforts in south Florida. 


\section{REFERENCES CITED}

Allen, E.R., and Sutton, R.L., 1990, Acidic deposition to north Florida forest ecosystems, in Watkins, C.E., ed., Florida Acidic Deposition Conference, October 1990, Tampa, Fla., p. 100-124.

Anderson, S.D., and Shaw, J.E., 1991, East Everglades ground water quality monitoring study, 1985-1986: West Palm Beach, Fla., South Florida Water Management District, Hydrogeology Division, Research and Evaluation Department, 91 p.

Aumen, N.G., 1995, History of human-related impacts to Lake Okeechobee, Florida (USA), related research, and lake management issues, in Aumen, N.G., and Wetzel, R.G., eds., Ecological studies on the littoral and pelagic systems of Lake Okeechobee, Florida (USA), Archiv fur Hydrobiologie Beiheft Ergebnis Limnologie, v. 45, p. 1-16.

Atkeson, T.D., 1994, Mercury in Florida's environment: Tallahassee, Florida Department of Environmental Protection, $2 \mathrm{p}$.

Baier, G., Cohn, T., and Gilroy, E., 1993, Instructions for using the Estimator software: U.S. Geological Survey, Reston, Va., 28 p.

Baker, L.A., 1991, Appendix B-Regional estimates of atmospheric dry deposition, in Charles, D.F., and Christie, S., Acidic deposition and aquatic ecosystems-Regional case studies: New York, SpringerVerlag.

Bason, C.W., and Colborn, Theo, 1992, U.S. application and distribution of pesticides and industrial chemicals capable of disrupting endocrine and immune systems, in Colborn, Theo, and Clement, Coralie, eds., Chemically-induced alterations in sexual and functional development: the wildlife/human connection: Princeton, N. J., Princeton Scientific Publishing Co., Inc., p. 335-345.

Bass, D.G., 1991, Riverine fishes of Florida, in Livingston, R.J., ed., The rivers of Florida: New York, SpringerVerlag, p. 65-84.

Belanger, T.V., Scheidt, D.J., and Platko, J.R., Jr., 1989, Effects of nutrient enrichment on the Florida Everglades: Lake and Reservoir Management, v. 5, no. 1, p. 101-111.

Bigelow, D.S., and Dossett, S.R., 1988, Instruction Manual, NADP/NTN Site Operation-National Atmospheric Deposition Program: Ft. Collins, Natural Resources Ecology Laboratory, Colorado State University.

Blasland, Bouck, and Lee, Inc., 1992, Evaluation and cost estimate for site restoration, Walker Ranch, Osceola County, Florida: Prepared for Walt Disney World Company, Lake Buena Vista, Florida, variously paged.
Bradner, L.A., 1991, Water quality in the Upper Floridan aquifer in the vicinity of drainage wells, Orlando, Florida: U.S. Geological Survey Water-Resources Investigations Report 90-4175, 57 p.

1994, Ground-water resources of Okeechobee County, Florida: U.S. Geological Survey Water-Resources Investigations Report 92-4166, $41 \mathrm{p}$.

Brezonik, P.L., Shapiro, J., and Swain, E., 1987, Floating blooms of the blue-green alga Anabaena circinalis in Lake Okeechobee: Causes, management alternatives: Final report submitted to the South Florida Water Management District, Department of Research, West Palm Beach.

Browder, J.A., Black, S., Schroeder, P., Brown, M., Newman, M., Cottrell, D., Black, D., Pope, R., and Pope, P., 1981, Perspective on the ecological causes and effects of the variable algal composition of Southern Everglades periphyton: Homestead, South Florida Research Center, Report T-643, 110 p.

Browder, P.L., Gleason, P.J., and Swift, D.R., 1994, Periphyton in the Everglades: spatial variation, environmental correlates, and ecological implications, in Davis, S.M., and Ogden, J.C., eds., Everglades ---the ecosystem and its restoration: Delray Beach, Fla., St. Lucie Press, p. 379-418.

Canfield, D.E., Jr., and Hoyer, M.Y., 1988, Influence of nutrient enrichment and light availability on the abundance of aquatic macrophytes in Florida streams: Canadian Journal of Fisheries and Aquatic Sciences, v. 45, no. 8, p. 1467-1472.

Carroll, J.D., and Banner, A. 1991, Kissimmee River Restoration Project, Fish and Wildlife Coordination Act Report: Vero Beach, Fla., U.S. Fish and Wildlife Service.

Carter, M.R., Burns, L.A., Cavinder, T.R., Dugger, K.R., Fore, P.L., Hicks, D.B., Revells, H.L., and Schmidt, T.W., 1973, Ecosystem analysis of the Big Cypress Swamp and estuaries: Atlanta, Ga., U.S. Environmental Protection Agency, variously paged.

Colborn, Theo, von Saal, F.S., and Soto, A.M., 1993, Developmental effects of endocrine-disrupting chemicals in wildlife and humans: Environmental Health Perspective, v. 101 , no. 5 , p. $378-386$.

Collier County Environmental Services Division, 1994, Sediment quality in inland waterways of Collier County, 1989-1991: Naples, Fla., Collier County Pollution Control Dept., Collier County Publication Series PC-AR-94-03.

Cooper, R.M., and Lane, J., 1987, An atlas of eastern Dade County surface water management basins: West Palm Beach, South Florida Water Management District Technical Memorandum. 
Cooper, R.M., and Roy, Joanne, 1991, An atlas of surface water management basins in the Everglades: the Water Conservation Areas and Everglades National Park: West Palm Beach, South Florida Water Management District Technical Memorandum, $88 \mathrm{p}$.

Craft, C.B., Vanmazal, J., and Richardson, C.J., 1995, Response of Everglades plant communities to nitrogen and phosphorus additions: Wetlands, v. 15, no. 3, p. 258-271.

Davis, D.L., and Bradlow, H.L., 1995, Can environmental estrogens cause breast cancer?: Scientific American, October 1995, p. 166-172.

Davis, J.H., Jr., 1943, The natural features of southern Florida, especially the vegetation, and the Everglades: Tallahassee, Florida Geological Survey, Geological Bulletin 25, 311 p.

Davis, S.M., 1991, Growth, decomposition and nutrient retention of Cladium jamaicense Crantz and Typha domingensis Pers. in the Florida Everglades: Aquatic Botany, v. 40, p. 203-224.

Davis, S.M., 1994, Phosphorus inputs and vegetation sensitivity in the Everglades, in Everglades-the ecosystem and its restoration, Davis, S.M., and Ogden, J.C., eds., Delray Beach, Fla., St. Lucie Press, p. 357-378.

Davis, S.M., Gunderson, L.H., Park. W.A., Richardson, J.R., and Mattson, J.E., 1994, Landscape dimension, composition, and function in a changing Everglades ecosystem, in Everglades-the ecosystem and its restoration, Davis, S.M., and Ogden, J.C., eds., Delray Beach, Fla., St. Lucie Press, p. 419-444.

Davis, L.J., Miller, S.J., and Wullschleger, J.G., 1990, Paradise Run fisheries investigations, in Loftin, M.K., Toth, L.A., and Obeysekera, J., eds., Proceedings of the Kissimmee River Restoration Symposium, October 1988, Orlando, Fla.: West Palm Beach, Fla., South Florida Water Management District, p. 149-159.

Delfino, J.J., and Crisman, T.L., 1993, Spatial and temporal distribution of mercury in Everglades and Okeefenokee wetland sediments: University of Florida, Final Project Report June, 1993.

Dickson, K.G., 1980, South Florida Water Management District Water Quality Monitoring Network 1980 Annual Report: West Palm Beach, South Florida Water Management District Technical Memorandum, $60 \mathrm{p}$.

Dickson, K.G., Federico, A.C., and Lutz, J.R., 1978, Water quality in the Everglades Agricultural Area and its impact on Lake Okeechobee: West Palm Beach, South Florida Water Management District Technical Publication 78-3, $132 \mathrm{p}$.

Dineen, J.W., 1974, The fishes of the Everglades, in Gleason, P.J. ed., Environments of South Florida, present and past: Miami Geological Society, Memoir 2, p. 375385 .
Drew, R.D., and Schomer, N.S., 1984, An ecological characterization of the Caloosahatchee River/Big Cypress watershed: Tallahassee, Florida Department of Environmental Regulation, $225 \mathrm{p}$.

Duerr, A.D., Hunn, J.D., Lewelling, B.R., and Trommer, J.T., 1988, Geohydrology and 1985 water withdrawals from the aquifer systems in southwest Florida, with emphasis on the intermediate aquifer system: U.S. Geological Survey Water-Resources Investigations Report $87-4259,115 \mathrm{p}$.

Duerr, A.D., and Enos, G.M., 1991, Hydrogeology of the intermediate aquifer system and Upper Floridan aquifer, Hardee and DeSoto Counties, Fla.: U.S. Geological Survey Water-Resources Investigations Report 904104, 46 p.

Duever, M.J., 1984, Environmental factors controlling plant communities of the Big Cypress Swamp, in Gleason, P.J., ed., Environments of south Florida, present and past 2: Miami Geological Society Memoirs, p. 127137.

Duever, M.J., Carlson, J.E., Meeder, J.F., Duever, L.C., Gunderson, L.H., Riopelle, L.A., Alexander, T.R., Myers, R.L., and Spangler, D.P., 1986, The Big Cypress Preserve: New York, National Audubon Society Research Report 8, 444 p.

Duever, M.J., Meeder, J.F., Meeder, L.C., and McCollom, J.M., 1994, The climate of south Florida and its role in shaping the Everglades ecosystem, in Davis, S.M., and Ogden, J.C., eds., Everglades - The ecosystem and its restoration: Delray Beach, Fla., St. Lucie Press, p. 225248.

Edgerton, E.S., and Lavery, T.F., 1990, Wet and dry deposition across the southeastern United States, in C.E. Watkins, ed., Proceedings of the Florida Acidic Deposition Conference: Tallahassee, Florida Department of Environmental Regulation, p. 88-99.

Environmental Science and Engineering, Inc., 1977, Final water quality report for the Caloosahatchee River study area, U.S. Environmental Protection Agency, Section 208 Water Quality Management program: Prepared for Southwest Florida Regional Planning Council.

Environmental Systems Research Institute, 1992, ARC/INFO User's Guide: GRID Command references functions G-Z, Inc., p. IDW 1-5.

Estevez, E.D., Dixon, L.K., and Flannery, M.S., 1991, West coastal rivers of peninsular Florida, in Livingston, R.J., ed., The rivers of Florida: New York, Springer-Verlag, p. 187-221.

Exotic Pest Plant Council, 1993, Exotic pest plant council's 1993 list of Florida's most invasive species: West Palm Beach, 5 p.

Federico, A.C., 1977, Investigations of the relationship between land use, rainfall, and runoff quality in the Taylor Creek Watershed: West Palm Beach, South Flor- 
ida Water Management District Technical Publication 77-3, $44 \mathrm{p}$.

---- 1982, Water quality characteristics of the Lower Kissimmee River Basin, Florida: West Palm Beach, South Florida Water Management District Technical Publication 82-3, 107 p.

----- 1983, Upper east coast water quality studies: West Palm Beach, South Florida Water Management District Technical Publication 83-1, 91 p.

Federico, A.C., Dickson, K.G., Kratzer, C.R., and Davis, F.E., 1981, Lake Okeechobee water quality studies and eutrophication assessment: West Palm Beach, South Florida Water Management District Technical Publication 81-2, $128 \mathrm{p}$.

Fennema, R.J., Neidrauer, C.J., Johnson, R.A., MacVicar, T.K., and Perkins, W.A., 1994, A computer model to simulate natural Everglades hydrology, in Davis, S.M., and Ogden, J.C., eds., Everglades-The ecosystem and its restoration: Delray Beach, Fla., St. Lucie Press, p. 249-290.

Flora, M.D., Walker, D.R., Scheidt, D.J., Rice, R.G., and Landers, D.H., 1988, Response of experimental loading, part 1: nutrient dosing, water chemistry, and periphyton production: National Park Service, Report to the Superintendent, South Florida Research Center, Homestead, Fla.

Florida Department of Environmental Regulation, 1988, 1988 Florida water quality assessment 305(b) technical appendix: Tallahassee, $289 \mathrm{p}$.

---- 1989, Florida Ground Water Guidance Concentrations: Tallahassee, $14 \mathrm{p}$.

--.- 1995, Florida surface water quality standards: Florida Administrative Code, chap. 62-302.

Florida Department of Natural Resources, 1974, Kissimmee-Everglades Area: Tallahassee, 180 p.

Florida Department of State, 1993, Rules of the Department of Environmental Protection, Public Drinking Water Systems: Florida Administrative Code, chap. 17-550.

Florida Geological Survey, 1992, Florida's ground water quality monitoring program: Background hydrogeochemistry: Florida Geological Survey Special Publication $34,364 \mathrm{p}$.

Fraser, T.H., 1991, The lower Peace River and Horse Creek: Flow and water-quality characteristics, 1976-1986, in Livingston, R.J. ed., The rivers of Florida: New York, Springer-Verlag, p. 143-186.

Frederick, P.C., and Spalding, M.G., 1994, Factors affecting reproductive success of wading birds (Ciconiiformes) in the Everglades ecosystem, in Davis, S.M., and Ogden, J.C., eds., Everglades-The ecosystem and its restoration: Delray Beach, Fla., St. Lucie Press, p. 659692.
Germain, G.J., 1994, Surface water quality monitoring network: West Palm Beach, South Florida Water Management District Technical Memorandum June 1994, $236 \mathrm{p}$.

German, E.R., (in press), Analysis of nonpoint-source ground-water contamination in relation to land use: Assessment of nonpoint-source contamination in central Florida: U.S. Geological Survey Water-Supply Paper 2381-F.

German, E.R., and Schiffer, D.M., 1988, Application of national stream quality accounting network (NASQAN) station data for assessing water quality in the Peace River Basin, Florida: U.S. Geological Survey Water-Resources Investigations Report 87-4167, 73 p.

Gleason, P.J., 1974, Chemical quality of water in Conservation Area 2A and associated canals. Technical Publication 74-1: West Palm Beach, Central and South Florida Flood Control District, Environmental Sciences Division, Resource Planning Department.

Gordon, A.S., Cooper, W.J., and Scheidt, D.J., 1986, Denitrification in marl and peat sediments in the Florida Everglades: Applied Environmental Microbiology, v. 52, no. 5, p. 987-991.

Graves, G.A., and Strom, D.G., 1992, Bessey Creek and the Greater St. Lucie Estuary: Port St. Lucie, Florida Department of Environmental Protection, $55 \mathrm{p}$.

---- 1995a, Pesticide contamination in Ten Mile CreekEcosystem Management Report: Port St. Lucie, Florida Department of Environmental Protection, $81 \mathrm{p}$.

---- 1995b, Update on pesticides in Martin and St. Lucie Counties: Port St. Lucie, Florida Department of Environmental Protection, $5 \mathrm{p}$.

Grieb, T.M., Driscoll, C.T., Gloss, S.P., Schofield, C.L., Bowie, G.L., and Porcella, D.B., 1990, Factors affecting mercury accumulation in fish in the Upper Michigan Peninsula: Environmental Toxicology and Chemistry, v. 9, p. 919-930.

Grimshaw, H.J., Rosen, Morris, Swift, D.R., Rodberg, Kevin, Noel, J.M., 1993, Marsh phosphorus concentrations, phosphorus content, and species composition of Everglades periphyton communities: Archive fur Hydrobiologie, v. 128, no. 3, p. 257-276.

Guimond, R.J., and Windom, S.T., 1975, Radioactivity distribution in phosphate products, by-products, effluents, and wastes: U.S. Environmental Protection Agency, Technical Note ORP/CSD-75-3, 32 p.

Hammett, K.M., 1990, Land use, water use, streamflow characteristics, and water-quality characteristics of the Charlotte Harbor inflow area, Florida: U.S. Geological Survey Water-Supply Paper 2359, 64 p. 
Harada, K., Burnett, W.C., LaRock, P.A., and Cowart, J.B., 1989, Polonium in Florida ground water and its possible relationship to the sulfur cycle and bacteria, Geochimica and Cosmochimica Acta, v. 53, p. 143150.

Haunert, D.E., 1988, Sediment characteristics and toxic substances in the St. Lucie Estuary: West Palm Beach, South Florida Water Management District Technical Publication 88-10, 42 p.

Haunert, D.E., and Startzman, J.R., 1985, short term effects of a freshwater discharge on the biota of St. Lucie Estuary, Florida: West Palm Beach, South Florida Water Management District Technical Publication 85-1, 65 p.

Herr, J.W., and Shaw, J.E., 1989, South Florida Water Management district ambient ground water quality: West Palm Beach, South Florida Water Management District Technical Publication 89-1, 275 p.

Howie, Barbara, 1987, Chemical characteristics of water in the surficial aquifer, Broward County, Florida: U.S. Geological Survey Water-Resources Investigations Report 86-4330, 2 sheets.

Irwin, G.A., and Bonds, J.L., 1987, Florida ground-water quality, in Moody, D.W., and others, compilers, National Water Summary 1986-Hydrologic events and ground-water quality: U.S. Geological Survey Water-Supply Paper 2325, p. 205-214.

Irwin, G.A., and Kirkland, R.T., 1980, Chemical and physical characteristics of precipitation at selected sites in Florida: U.S. Geological Survey Water-Resources Investigations Report 80-81, $70 \mathrm{p}$.

Irwin, G.A., and Swihart, T.M., 1993, Florida stream-water quality, in Paulson, R.W., Chase, E.B., Williams, J.S., and Moody, D.W., compilers, National Water Summary 1990-91-Hydrologic Events and Stream Water Quality: U.S. Geological Survey Water-Supply Paper 2400, $590 \mathrm{p}$.

Janus, L.L., Sobaalle, D.M., and Jones, B.L., 1990, Nutrient budget analyses and phosphorus loading goal for Lake Okeechobee, Florida: Verhein Internationale Verein Limnologique, v. 24, p. 538-546.

Jones, B.L., 1987, Lake Okeechobee eutrophication research and management: Aquatics, v. 9, p. 21-26.

Katz, B.G., 1993, Biogeochemical and hydrological processes controlling the transport and fate of 1,2-Dibromoe-thane (EDB) in soil and ground water, central Florida: U.S. Geological Survey Water-Supply Paper 2402, 35 p.

Kaufmann, R.F., and Bliss, J. D., 1977, Effects of phosphate mineralization and the phosphate industry on radium226 in ground water of central Florida; U.S. Environmental Protection Agency Report EPA/520-6-77-010, $115 \mathrm{p}$.
Kimrey, J.O., and Fayard, L.D., 1984, Geohydrologic reconnaissance of drainage wells in Florida: U.S. Geological Survey Water-Resources Investigations Report 84-4021, $67 \mathrm{p}$.

Klein, Howard, Schneider, W.J., McPherson, B.F., and Buchanan, T.J., 1970, Some hydrologic and biologic aspects of the Big Cypress Swamp drainage area, southern Florida: U.S. Geological Survey Open-File Report 70003, 94 p.

Kolipinski, M.C., and Higer, A.L., 1969, Some aspects of the effects of the quantity and quality of water on biological communities in Everglades National Park: U.S. Geological Survey Open-File Report 69007, 97 p.

Kolipinski, M.C., Higer, A.L., and Yates, M.L., 1971, Organochlorine insecticide residues in Everglades National Park and Loxahatchee National Wildlife Refuge, Florida: Pesticides Monitoring Journal, v. 5, no. 3, p. 281-288.

Krabbenhoft, D.P., and Rickert, D.A., 1995, Mercury contamination in aquatic ecosystems: U.S. Geological Survey Fact Sheet FS-216-95, 4 p.

Kushlan, J.A., 1976, Environmental stability and fish community diversity: Ecology, v. 57, p. 821-825.

----- 1991, The Everglades, in Livingston, R.J., ed., The rivers of Florida: New York, Springer-Verlag, p. 121-142.

Kutz, F.W., Yobs, A.R., and Yang, S.C., 1976, National pesticide monitoring programs, in Lee, R.E., Jr., ed., Air pollution from pesticides and agricultural processes: Cleveland, Ohio, CRC Press, p. 95-136.

Lange, T.R, Royals, H.E., and Connor, L.L., 1993, Influence of water chemistry on mercury concentrations in largemouth bass from Florida lakes: Transactions of the American Fisheries Society, v. 122, p. 74-84.

LaRose, H.R., 1990, Geohydrologic framework and an analysis of a well-plugging program, Lee County, Florida: U.S. Geological Water-Resources Investigations Report 90-4063, 26 p.

Lewelling, B.R., and Wylie, R.W., 1993, Hydrology and water quality of unmined and reclaimed basins in phosphate-mining areas, west-central Florida: U.S. Geological Survey Water-Resources Investigations Report 93-4002, 93 p.

Lindall, W.N., Jr., 1973, Alterations of estuaries of south Florida-A threat to its fish resources: Marine Fisheries Review, v. 35 , no. 10 , p. 26-33.

Livingston, R.J. ed., 1991, The rivers of Florida: New York, Springer-Verlag, $289 \mathrm{p}$.

Loftin, M.K., Toth, L.A., and Obeysekera, J.T.B., 1990a, Kissimmee River Restoration: Alternative plan evaluation and preliminary design report: West Palm Beach, South Florida Water Management District, 147 p. 
----- eds., 1990b, Proceedings of the Kissimmee River Restoration Symposium: Orlando, Florida, USA, October 1988, West Palm Beach, South Florida Water Management District.

Loftus, W.F., Chapman, J.D., and Conrow, R., 1990, Hydroperiod effects on Everglades marsh food webs, with relation to marsh restoration efforts: Proceedings of the Fourth Triennial Conference on Science in the National Parks, 1986, Fort Collins, Colo., p. 1-22.

Loftus, W.F., and Eklund, Ann-Marie, 1994, Long-term dynamics of an Everglades small-fish assemblage, in Davis, S.M., and Ogden, J.C. eds., Everglades - The ecosystem and its restoration: Delray Beach, Fla., St. Lucie Press, p. 461-484.

Loftus, W.F., and Kushlan, J.A., 1987, Freshwater fish of southern Florida: Bulletin of the Florida State Museum of Biological Sciences, v. 31, p. 147-344.

Lopez, M.A., and Giovannelli, R.F., 1984, Water-quality characteristics of urban runoff and estimates of annual loads in the Tampa Bay area, Florida, 1975-80: U.S. Geological Survey Water-Resources Investigations Report 83-4181, 76 p.

Lutz, J.R., 1977a, Water quality characteristics of several southeast Florida canals: West Palm Beach, South Florida Water Management District Technical Publication 77-4, $83 \mathrm{p}$.

---- 1977b, Water quality and nutrient loadings of the major inflows from the Everglades Agricultural Area to the Conservation Areas, Southeast Florida: West Palm Beach, South Florida Water Management District Technical Publication 77-6, 40 p.

Majewski, M.S., and Capel, P.D., 1995, Pesticides in the atmosphere-Distribution, trends, and governing factors: Chelsea, Mich., Ann Arbor Press, 214 p.

Marella, R.L., 1993, Public-supply water use in Florida, 1990: U.S. Geological Survey Open-File Report 93-134, 46 p.

----- 1994, Estimated discharge of treated wastewater in Florida, 1990: U.S. Geological Survey Open-File Report 93-364, p. 15.

McPherson, B.F., 1969, Preliminary determinations of hydrobiological and chemical conditions in the vicinity of the proposed jetport and other airports in South Florida: U.S. Geological Survey Progress Report, 45 p.

----- 1973, Water quality in the conservation areas of the central and southern Florida Flood Control District, 1970-72: U.S. Geological Survey Open-File Report 73014, 39 p.

---- 1974, The Big Cypress Swamp, in Gleason, P.J. ed., Environments of south Florida, present and past: Miami Geological Society, Memoir 2, p. 8-17.

----- 1984, The Big Cypress Swamp, in Gleason, P.J. ed., Environments of south Florida: present and past II: Miami Geological Society, p. 69-78.
----- 1994, National Water Quality Assessment Program, southern Florida: U.S. Geological Survey Open-File Report 94-57, 2 p.

McPherson, B.F., and Halley, Robert, 1996, The south Florida environment-A region under stress, U.S. Geological Survey Circular 1134, 61 p.

Mercury Technical Committee, 1991, Interim Report to the Florida Governor's Mercury in Fish and Wildlife Task Force and the Florida Department of Environmental Regulation: Tallahassee, $60 \mathrm{p}$.

Miller, J., and Morris, J., 1981, The Peace River, in Estevez, E.D., ed., A review of scientific information: Charlotte Harbor (Florida) Estuarine Ecosystem Complex, Mote Marine Laboratory Review Series No. 3.

Miller, R.L., 1992, Ion-exchange control of Ra-226 activities in ground water of Sarasota County, Florida, in Gohn, G.S., ed., Proceedings of the 1988 U.S. Geological Survey Workshop on the Geology and Geohydrology of the Atlantic Coastal Plain: U.S. Geological Survey Circular 1059, p. 135-137.

Miller, R.L., Kraemer, T.F., and McPherson, B.F., 1990, Radium and radon in Charlotte Harbor Estuary, Florida: Estuarine, Coastal and Shelf Science, v. 31, p. 439457.

Miller, R.L., and McPherson, B.F., 1987, Concentration and transport of phosphorus and radium-226 in the Peace River and Charlotte Harbor, southwestern, Florida: Preprints of Papers Presented at the 194th National Meeting, Division of Environmental Chemistry, American Chemical Society, New Orleans, La., Aug. 30-Sept. 4, 1987 , v. 27, no. 2, p. 389-391.

Miller, R.L., and Sutcliffe, Horace., Jr., 1984, Effects of three phosphate sites on ground-water quality in central Florida, 1979-1980: U.S. Geological Survey WaterResources Investigations Report 83-4256, 184 p.

---- 1985, Occurrence of natural radium-226 radioactivity in ground water in Sarasota County, Florida, 19791980: U.S. Geological Survey Water-Resources Investigations Report 84-4237, 34 p.

Miller, T.H., Federico, A.C., and Milleson, J.F., 1982, A survey of water quality characteristics and chlorophyll $a$ concentrations in the Caloosahatchee River system, Florida: West Palm Beach, South Florida Water Management District Technical Publication 82-4, 155 p.

Miller, W.L., 1988, Description and evaluation of the effects of urban and agricultural development on the surficial aquifer system, Palm Beach County, Florida: U.S. Geological Survey Water-Resources Investigations Report 88-4056, 58 p.

Milleson, J.F., Goodrick, R.L., Van Arman, J.A., 1980, Plant communities of the Kissimmee River valley: West Palm Beach, South Florida Water Management District Technical Publication 80-7, 42 p. 
Nagda, N.L., Koontz, M.D., Fortmann, R.C., Schoenborn, W.A., and Mehegan, L.L., 1987, Florida statewide radiation study: Bartow, Florida Institute of Phosphate Research, $445 \mathrm{p}$.

National Academy of Sciences, 1978, An assessment of mercury in the environment: Washington, D.C., National Academy of Sciences, $185 \mathrm{p}$.

National Atmospheric Deposition Program, 1994, NADP/NTN annual data summary-Precipitation chemistry in the United States, 1993: Fort Collins, Colorado State University, $465 \mathrm{p}$.

Pait, A.S., DeSouza, A.E., Farrow, D.R.G., 1992, Agricultural pesticide use in coastal areas: A national summary: Rockville, Md., Strategic Environmental Assessments Division, National Oceanic and Atmospheric Administration.

Parker, G.G., 1974, Hydrology of the pre-drainage system of the Everglades in southern Florida, in P.J. Gleason, ed., Environments of south Florida, present and past: Miami Geological Society Memoir 2, p. 18-27.

Parker, G.G., Ferguson, G.E., and Love, S.K., and others, 1955, Water resources of southeastern Florida: U.S. Geological Survey Water-Supply Paper 1255, 965 p.

Paul, J.H., Rose, J.B., Jiang, Sunny, Kellog, Chris, Shin, E.A., 1995, Occurrence of fecal indicator bacteria in surface waters and subsurface aquifer in Key Largo, Florida: Applied Environmental Microbiology, June, p. 2235-2241.

Peden, M.E., 1986, Methods of collection and analysis of wet deposition: Champaign, Ill., Illinois State Water Survey, Report 381, 284 p.

Peters, N.E., and Reese, R.S., 1994, Variations of weekly atmospheric deposition for multiple collectors at a site on the shore of Lake Okeechobee, Florida: Atmospheric Environment, v. 29, no. 2, p. 179-187.

Pfeuffer, R.J., 1985, Pesticide residue monitoring in sediment and surface water bodies within the South Florida Water Management District: West Palm Beach, South Florida Water Management District Technical Publication $85-2,50 \mathrm{p}$.

---- 1991, Pesticide residue monitoring in sediment and surface water within the South Florida Water Management District: West Palm Beach, South Florida Water Management District Technical Publication 91-01, v. 2, $61 \mathrm{p}$.

Phlips, E.J., Aldridge, F.J., and Hansen, P. 1994, Patterns of water chemistry, physical and biological parameters in a shallow subtropical lake (Lake Okeechobee, Florida, USA), Archives fur Hydrobiologie, Beiheft = Advances in Limnology, v. 45, p. 117-135.

Puckett, L.J., 1994, Nonpoint and point sources of nitrogen in major watersheds of the United States: U.S. Geological Survey Water-Resources Investigations Report 94-4001, 6 p.
Radell, M.J., and Katz, B.G., 1991, Major-ion and selected trace-metal chemistry of the Biscayne aquifer, southeast Florida: U.S. Geological Survey Water-Resources Investigations Report 91-4009, 18 p.

Rader, R.B., and Richardson, C.J., 1992, The effects of nutrient enrichment on algae and macroinvertebrates in the Everglades: A review: Wetlands, v. 12, no. 2, p. 121-135.

Reddy, K.R., DeLaune, R.D., DeBusk, W.F., and Koch, M.S., 1993, Long-term nutrient accumulation rates in the Everglades: Journal of the Soil Science Society of America, v. 57, p. 1147-1155.

Requejo, A.G., West, R.H., Hatcher, P.G., and McGillivary, P.A., 1979, Polychlorinated biphenyls and chlorinated pesticides in soils of the Everglades National Park and adjacent agricultural areas: Environmental Science and Technology: v. 13, no. 8, p. 931-935.

Richardson, C.J., 1994, Effects of nutrient loadings and hydroperiod alterations on control of cattail expansion, community structure, and nutrient retention in the Water Conservation Areas of south Florida, Annual Report: Durham, N.C., Duke Wetlands Center Publication $94-08,368 \mathrm{p}$.

Robertson, W.B., Jr., and Frederick, P.C., 1994, The faunal chapters: contexts, synthesis, and departures, in Davis, S.M., and Ogden, J.C., eds., Everglades-The ecosystem and its restoration: Delray Beach, Fla., St. Lucie Press, p. 709-740.

Roelke, M.E., Schultz, D.P., Facemire, C.F., Sundlof, S.F., Royals, H.E., 1991, Mercury contamination in Florida panthers: Technical Subcommittee of the Florida Panther Interagency Committee.

Rutter, R.P., Sessions, D.E., Sloane, G.M., Winkler, D.A., 1986, Kissimmee River Restoration Project: Pre-construction Monitoring: Punta Gorda, Florida Department of Environmental Regulation, $14 \mathrm{p}$.

Rutter, R.P., Sessions, D.E., Winkler, D.A., 1989, Kissimmee Restoration Project: Post-Construction Monitoring: Punta Gorda, Florida Department of Environmental Regulation, 9 p.

Scheidt, D.J., 1989, Pesticides and Everglades National Park: South Florida use and threat, in Symposium on Wetlands: Concerns and successes, Tampa, Fla., September 1989: American Water Resources Association, p. $365-375$.

Scheidt, D.J., Flora, M.D., and Walker, D.R., 1989, Water quality management for Everglades National Park, in Symposium on wetlands: Concerns and successes, Tampa, Fla., September 1989: American Water Resources Association, p. 377-390.

Schinn, E.A., Reese, R.S., and Reich, C.D., 1994, Fate and pathways of injection-well effluent in the Florida Keys: U.S. Geological Survey Open-File Report 94-276, $116 \mathrm{p}$. 
Science Sub-Group, 1994, South Florida ecosystem restoration: scientific information needs: Draft, September 27, 1994, Management and Coordination Working Group, Interagency Task Force on the South Florida Ecosystem, $536 \mathrm{p}$.

Sherwood, C.B., McCoy, H.J., and Galliher, C.F., 1973, Water Resources of Broward County, Florida: Florida Bureau of Geology Report of Investigations 65, $141 \mathrm{p}$.

Simonich, S.L., and Hites, R.A., 1995, Global distribution of persistent organochlorine compounds: Science, v. 269 , p. $1851-1854$.

Sonenshein, R.S., and Hofstetter, R.H., 1990, Hydrologic effects of well-field operations in a wetland, Dade County, Florida: U.S. Geological Survey WaterResources Investigations Report 90-4143, 16 p.

Sonenshein, R.S., 1995, A hydrogeologic approach to identify land uses that overlie ground-water flow paths, Broward County, Florida: U.S. Geological Survey Water-Resources Investigations Report 94-4167, 59 p.

Sonntag, W.H., 1987, Chemical characteristics of water in the surficial aquifer system, Dade County, Florida: U.S. Geological Survey Water-Resources Investigations Report 87-4080, 42 p., 2 pls.

South Florida Water Management District, 1989, Interim Surface Water Improvement and Management (SWIM) Plan for Lake Okeechobee, Part I: Water Quality, and Part VII: Public Information: West Palm Beach, South Florida Water Management District, $150 \mathrm{p}$.

----- 1991, Design of a restoration Evaluation Program: West Palm Beach, South Florida Water Management District.

----- 1992a, Surface Water Improvement and Management Plan for the Everglades-Planning Document: West Palm Beach, South Florida Water Management District, $202 \mathrm{p}$.

----- 1992b, Surface Water Improvement and Management Plan for the Everglades-Supporting Information Document: West Palm Beach, South Florida Water Management District, $471 \mathrm{p}$.

---- 1993, Draft Kissimmee River Research Plan: West Palm Beach, South Florida Water Management District.

----- 1993, Average discharge data from a historical water balance (1980 to 1989), Appendices and technical information in support of the Lower East Coast Regional Water Supply Plan (draft working document): West Palm Beach.

---- 1994a, Surface water improvement and management plan for Biscayne Bay: West Palm Beach, South Florida Water Management District, variously paged.

---- 1994b, Everglades 1994 Annual Report: West Palm Beach, South Florida Water Management District, 32 p. 1995, Everglades, 1995 Annual Report: West Palm Beach, South Florida Water Management District, 40 p.
Stansland, C.L., Peden, M.E., and Bowersox, V.C., 1983, NADP quality control procedures for wet deposition sample collection and field measurements: 76th Annual APCA Meeting, Atlanta, Ga., June 1983, Paper No. 83-32.2.

State of Florida, Department of Agriculture and Consumer Services, 1993, Summary report of fertilizer materials and fertilizer mixtures consumed in Florida: Fiscal Year Report July 1, 1992-June 30, 1993.

Steward, K.K., and Ornes, W.H., 1975, The autecology of sawgrass in the Florida Everglades: Ecology, v. 56, no. 1, p. 162-171.

Steward, J., Virnstein, R., Haunert, D., and Lund, F., eds., 1993, Draft surface water improvement and management (SWIM) plan for the Indian River Lagoon: West Palm Beach, South Florida Water Management District.

Stober, Q.J., Jones, R.D., and Scheidt, D.J., 1994, Ultra trace level mercury in the Everglades ecosystem, a multimedia canal pilot study, in International Conference on mercury as a global pollutant: Whistler, British Columbia, $11 \mathrm{p}$.

---- 1995, Ultra trace level mercury in the Everglades ecosystem. a multi-media canal pilot study: Water, Air, and Soil Pollution, v. 80, p. 991-1001.

Sumner, D.M., and Bradner, L.A., 1996, Hydraulic characteristics and nutrient transport and transformation beneath a rapid infiltration basin, Reedy Creek Improvement District, Florida: U.S. Geological Survey Water-Resources Investigations Report 95-4281, 51 p.

Swancar, Amy, 1996, Water quality, pesticide occurrence, and effects of irrigation with reclaimed water at golf courses in Florida: U.S. Geological Survey WaterResources Investigations Report 95-4250, 85 p.

Swift, D.R., 1984, Periphyton and water quality relationships in the Everglades Water Conservation Areas, in Gleason, P.J., ed., Environments of south Florida, present and past II: Miami Geological Society, p. 97-117.

Swift, D.R., and Nicholas, R.B., 1987, Periphyton and water quality relationships in the Everglades Water Conservation Areas, 1978-1982: West Palm Beach, South Florida Water Management District, Technical Publication $87-2,44 \mathrm{p}$.

Tabor, E.C., 1965, Pesticides in urban atmosphere: Journal of the Air Pollution Control Association, v. 15, no. 9, p. 415-418.

Tchobanoglous, George, 1991, Wastewater engineering treatment, disposal, and use ( $3 \mathrm{~d}$ ed.): Metcalf and Eddy, Inc., $1334 \mathrm{p}$.

Thomas, T.M., 1974, A detailed analysis of climatological and hydrological records of south Florida with reference to man's influence upon the ecosystem evolution, in Gleason, P.J., ed., Environments of South Florida, present and past: Miami Geological Society Memoir 2, p. 82-122. 
Toth, L.A., 1993, The ecological basis of the Kissimmee River restoration plan: Biological Sciences, v. 1, p. 25-51.

Toth, L.A., Obeysekera, J.T.B., Perkins, W.A., and Loftin, M.K. 1993, Flow regulation and restoration of Florida's Kissimmee River: Regulated Rivers: Research and Management, v. 8, p. 155-166.

Trommer, J.T., 1993, Description and monitoring of the saltwater-freshwater transition zone in aquifers along the west-central coast of Florida: U.S. Geological Survey Water-Resources Investigations Report 93-4120, $56 \mathrm{p}$.

U.S. Army Corps of Engineers, 1991, Environmental Restoration Kissimmee River, Florida: Jacksonville, Fla.

U.S. Department of Commerce, Bureau of Census, 1990 Census of Population and Housing: Public Law 94-171.

U.S. Environmental Protection Agency, 1972, Dade, Collier, and transition jetport air pollution study, MarchMay, 1972: Atlanta, Ga., Office of Air Programs.

---- 1993, R-EMAP: Regional Environmental Monitoring and Assessment Program: Cincinnati, Ohio, EPA/625/R-93/012, $82 \mathrm{p}$.

U.S. Geological Survey, 1995, South Florida Ecosystem Program of the U.S. Geological Survey: Fact Sheet FS-135-95, 4 p.

Urban, N.H., Davis, S.M., and Aumen, N.G., 1993, Fluctuations in sawgrass and cattail densities in Everglades Water Conservation Area 2A under varying nutrient, hydrologic and fire regimes, Aquatic Botany: v. 46, p. 203-223.

Vincent, J.R., 1984, South Florida drinking water investigation, Broward, Dade, and Palm Beach Counties: U.S. Environmental Protection Agency, EPA-330/1-84-001.

Walker, W.W., 1991, Water quality trends at inflows to Everglades National Park: Water Resources Bulletin, v. 27 , no. 1 , p. 59-71.

Waller, B.G., 1975, Distribution of nitrogen and phosphorus in the conservation areas in south Florida from July 1972 to June 1973: U.S. Geological Survey WaterResources Investigations Report 5-75 (ADA-012 347), $33 \mathrm{p}$.
----- 1976, Analysis of selected benthic communities in Florida Everglades with reference to their physical and chemical environments. U.S. Geological Survey WaterResources Investigations Report 76-28 (ADA-025 593), $33 \mathrm{p}$.

---- 1982, Water quality characteristics of Everglades National Park, 1959-77 with reference to the effects of water management: U.S. Geological Survey WaterResources Investigation Report 82-34, $51 \mathrm{p}$.

Waller, B.G. and Earle, J.E., 1975, Chemical and biological quality of water in part of the Everglades, southeastern Florida: U.S. Geological Survey Water-Resources Investigations Report 56-75 (ADA-028 795), 157 p.

Walters, C.J., Gunderson, L.H., and Holling, C.S., 1992, Experimental policies for water management in the Everglades: Applied Ecology, v. 2, p. 189-202.

Ware, F.J., Royals, H.E., and Lange, T.R., 1990, Mercury contamination in Florida largemouth bass: Proceedings of the Annual Conference Southeastern Association of Fish and Wildlife Agencies, v. 44, p. 5-12.

Whalen, P.J., VanArman, J., Mulliken, J., Swift, D., Bellmund, S., Worth, D.F., Fontaine, T.D., Gulick, L., and Formati, S., 1992, Draft Surface Water Improvement and Management Plan for the Everglades: West Palm Beach, South Florida Water Management District.

Worth, D.F., 1988, Environmental response of WCA-2A to reduction in regulation schedule and marsh drawdown: West Palm Beach, South Florida Water Management District Technical Publication 88-2, 55 p.

Zarbock, Hans, Janicki, Anthony, Wade, David, Heimbuch, Douglas, and Wilson, Harold, 1994, Estimates of total nitrogen, total phosphorus, and total suspended solids loadings to Tampa Bay, Florida: Tampa Bay National Estuary Program Report 04-94, variously paged. 


\title{
Appendix
}

\section{Data Sources and Computation Methods Used for Pie Diagrams of Estimated}

\author{
Nutrient Loads in Southern Florida
}

\section{Fertilizer and Manure}

Fertilizer and manure loads were calculated using a combination of county-level estimates for fertilizer and manure and large-scale land use and land cover (LULC) digital maps. Fertilizer estimates were obtained from the Florida Department of Agriculture and Consumer Services. Manure data were computed by R.B. Alexander (U.S. Geological Survey, written commun., 1992) using data on county animal populations obtained from the 1987 Census of Agriculture and the manure nutrient content in units of kilograms per year as $\mathrm{N}$ and $\mathrm{P}$. Computations are based on estimates of the nutrient content of daily wastes produced per $454 \mathrm{~kg}$ of animal weight. Estimates obtained from the Soil Conservation Service, April 1992, the Agricultural Waste Management Field Handbook, Chapter 4. Estimates of nutrient content, in some cases, represent an average of the reported range of values or are assumed values.

Fertilizer and manure data were available for each county in the study unit, but not for the designated surfacewater basins. In order to determine estimates for the designated surface-water basins, it was necessary to determine the proportion of cropland in the basins for fertilizer estimates and the proportion of other agricultural land in the basins for manure estimates, compared to total cropland and total other agricultural land in the county. The proportion of cropland was used to calculate the fertilizer use estimates for the basin. The proportion of other agricultural land was used to calculate the manure estimates for the basin.

The cropland estimates used are based on Water Management District (WMD) land cover and land use digital maps. The Southern Florida NAWQA study unit falls under the jurisdictions of three Water Management Districts: South Florida (SFWMD), Southwest Florida (SWFWMD), and St. Johns River (SJRWMD). The LULC data for SFWMD were compiled in 1988. SWFWMD LULC digital maps were compiled from aerial photography dated from 1989-91. SJRWMD LULC digital maps were compiled from aerial photography dated from 1986-91.

The specific LULC classification systems differed slightly between Water Management Districts. For SFWMD, the following LULC categories were used for the fertilizer calculations: cropland, including sugar cane, truck crops, rice groves, ornamentals, nurseries, tropical fruits, and sod farms. For manure calculations the following LULC categories were used: improved and unimproved pasture, confined feeding operations, including cattle, dairy, fish, horse, and poultry farms.
For SWFWMD and SJRWMD, the following categories were used for fertilizer calculations: row crops, field crops, citrus, fruit, other groves, tree nurseries, sod farms, ornamentals, vineyards, floriculture, and timber seedlings. For manure calculations, the following categories were used: pasture, improved pastured, woodland pasture, feeding operations, including, cattle, poultry, swine, horse, dairies, kennels, and fish farms.

\section{Atmospheric Deposition}

Three South Florida Water Management District precipitation-quality sites were used. These sites were selected where water quality could be matched with data from nearby daily precipitation-quality collectors. Only precipitationquality data collected after March 1992 were used (when SFWMD began using NADP protocols). The precipitationquantity data (wetfall only) were summed for the 7 days preceding the Tuesday morning collection of the precipitationquality sample. This approach was used because precipitation often falls in the afternoon or evening during much of the year. If precipitation-quantity/quality data were missing, the nearest before and after data were averaged to compute an estimated value to avoid assuming zero loading during the gaps in data. To compute the weekly atmospheric loading, the 7-day sum of precipitation quantity in inches was multiplied by the concentration of total nitrogen or total phosphorus in milligrams per liter and by a conversion factor of $25.4 \mathrm{~L} \mathrm{~kg} \mathrm{mg}^{-1} \mathrm{inch}^{-1} \mathrm{~km}^{-2}$ to get a weekly loading in kilograms per square kilometer. The weekly periods at the beginning and end of the 1- or 2-year summing period were adjusted by multiplying by the number of days in the period of computation and then dividing by 7 days. The weekly sums were then added together to get total atmospheric loading. If a 2-year period was summed the load was divided by 2 to get an annual atmospheric loading of total nitrogen or total phosphorus in kilograms $(\mathrm{kg})$ of $\mathrm{N}$ or $\mathrm{P}$ per square kilometer $\left(\mathrm{km}^{2}\right)$ per year. The designated basins were converted to a grid consisting of $1-\mathrm{km}^{2}$ grid cells. The three annual average precipitation loadings were interpolated/extrapolated to the centers of the grid cells using the ARC/INFO inverse distance weighting function. The interpolated/ extrapolated values were summed to produced total nitrogen and phosphorus loads per basin. 
Total atmospheric deposition of nitrogen and phosphorus includes wet and dry components, although the dry deposition is generally not measured and is poorly understood (Edgerton and Lavery, 1990); total deposition is usually estimated using a ratio of dry to wet deposition (Gerald Morrison, South Florida Water Management District, written commun., 1992). Estimates of the dryfall to wetfall ratio in Florida range from $0.30\left(\mathrm{CH}_{2} \mathrm{M}\right.$ Hill, 1992) to 2.04 (Environmental Science and Engineering, 1977; Zarback and others, 1994). We have chosen the lower ratio as a conservative estimate for southern Florida and have multiplied the wet deposition by 1.3 to obtain a total atmospheric deposition.

\section{Septic Tanks}

The nitrogen and phosphorus loads for septic tanks were calculated using county estimates of septic tank numbers and drainage basin population data. The septic tank data were obtained from Marella (1994). In order to determine the number of septic tanks within each basin from the county estimate, the proportion of population within the basin was calculated from county population estimates for census block groups. For example, if 90 percent of a county's 1990 population lived within a given basin, then 90 percent of the septic tanks for that county were allocated to that basin.

In order to determine nitrogen and phosphorus loads from numbers of septic tanks, estimates were obtained for the amount of nitrogen and phosphorus potentially generated by a septic tank. According to Tchobanoglous (1991), 11 $\mathrm{kg} / \mathrm{yr}$ of nitrogen and $4 \mathrm{~kg} / \mathrm{yr}$ of phosphorus can be generated per septic tank. Therefore, the number of septic tanks in a given basin was multiplied by 11 and 4 to obtain nitrogen and phosphorus loads, respectively, for that basin.

\section{Major Canals and Rivers}

Loads of total phosphorus and total nitrogen from major canals and rivers were estimated for use in table 3 and figures 5 and 6. For most sites, these loads were estimated using average annual discharge during 1980-89 (South Florida Water Management District, 1993) reported in 1,000 acrefeet per year times the mean concentration of total phosphorus or total nitrogen (Germain, 1994) reported in milligrams per liter times a unit conversion factor of 1233.482 ( $\mathrm{L}$ $\mathrm{kg}$ )/(thousands acre- $\mathrm{ft} \mathrm{mg}$ ). The computation was done using a FORTRAN program.
Loads for 3 major canals and rivers were computed from different data sources. Loads for the Peace River at Arcadia were computed from USGS discharge and nutrient-concentration data collected during 1984-93 using the Estimator program written by Timothy Cohn of the USGS. The use of Estimator is described by Baier and others (1993). The nutrient loads for the St. Lucie Canal were estimated using the mean USGS discharge data for the St. Lucie Canal at structure S80 collected during 1953-91 and the mean nutrient concentration data collected during 1989-91 by Germain (1994). Nutrient loads to the Big Cypress Basin were estimated from USGS discharge data collected during 1964-94 at 40-Mile Bend to Monroe and mean nutrient concentration data collected at Tamiami Trail Bridge 105, as reported in the SFWMD data base (DBHYDRO) from 1984-93.

\section{Wastewater Treatment Facilities}

Nitrogen and phosphorus loads generated by wastewater treatment facilities were calculated using wastewater discharge amounts and disposal source. The amount of nutrients in wastewater is determined primarily by the level of treatment. Most wastewater treatment in Florida is secondary (Sharon Sowicki, Florida Department of Environmental Protection, written commun., 1996). Only those facilities that discharged wastewater within the designated basins were included in the calculations. Wastewater treatment facilities that discharged treated wastewater directly to the Atlantic Ocean were removed from the calculations. According to David York (Florida Department of Environmental Protection, Draft Domestic Wastewater Management Section for Chapter 10 (Water Management Programs), Florida Water Atlas, table 1, written commun., 1996), secondarily treated wastewater can contain $15 \mathrm{mg} / \mathrm{L}$ nitrogen and 8 $\mathrm{mg} / \mathrm{L}$ phosphorus, so these amounts, along with the discharge amounts, were used to determine nitrogen and phosphorus loads. 